\title{
What could have caused pre-industrial biomass burning emissions to exceed current rates?
}

\author{
G. R. van der Werf ${ }^{1}$, W. Peters ${ }^{2}$, T. T. van Leeuwen ${ }^{1}$, and L. Giglio ${ }^{3}$ \\ ${ }^{1}$ Faculty of Earth and Life Sciences, VU University Amsterdam, Amsterdam, The Netherlands \\ ${ }^{2}$ Department of Meteorology and Air Quality, Wageningen University, Wageningen, The Netherlands \\ ${ }^{3}$ Department of Geographical Sciences, University of Maryland, College Park, Maryland, USA
}

Correspondence to: G. R. van der Werf (grvdwerf@gmail.com)

Received: 11 July 2012 - Published in Clim. Past Discuss.: 3 August 2012

Revised: 22 December 2012 - Accepted: 10 January 2013 - Published: 31 January 2013

\begin{abstract}
Recent studies based on trace gas mixing ratios in ice cores and charcoal data indicate that biomass burning emissions over the past millennium exceeded contemporary emissions by up to a factor of 4 for certain time periods. This is surprising because various sources of biomass burning are linked with population density, which has increased over the past centuries. We have analysed how emissions from several landscape biomass burning sources could have fluctuated to yield emissions that are in correspondence with recent results based on ice core mixing ratios of carbon monoxide (CO) and its isotopic signature measured at South Pole station (SPO). Based on estimates of contemporary landscape fire emissions and the TM5 chemical transport model driven by presentday atmospheric transport and $\mathrm{OH}$ concentrations, we found that $\mathrm{CO}$ mixing ratios at $\mathrm{SPO}$ are more sensitive to emissions from South America and Australia than from Africa, and are relatively insensitive to emissions from the Northern Hemisphere. We then explored how various landscape biomass burning sources may have varied over the past centuries and what the resulting emissions and corresponding $\mathrm{CO}$ mixing ratio at SPO would be, using population density variations to reconstruct sources driven by humans (e.g., fuelwood burning) and a new model to relate savanna emissions to changes in fire return times. We found that to match the observed ice core CO data, all savannas in the Southern Hemisphere had to burn annually, or bi-annually in combination with deforestation and slash and burn agriculture exceeding current levels, despite much lower population densities and lack of machinery to aid the deforestation process. While possible, these scenarios are unlikely and in conflict with current literature. However, we do show the large potential for increased
\end{abstract}

emissions from savannas in a pre-industrial world. This is mainly because in the past, fuel beds were probably less fragmented compared to the current situation; satellite data indicates that the majority of savannas have not burned in the past $10 \mathrm{yr}$, even in Africa, which is considered "the burning continent". Although we have not considered increased charcoal burning or changes in $\mathrm{OH}$ concentrations as potential causes for the elevated $\mathrm{CO}$ concentrations found at SPO, it is unlikely they can explain the large increase found in the $\mathrm{CO}$ concentrations in ice core data. Confirmation of the $\mathrm{CO}$ ice core data would therefore call for radical new thinking about causes of variable global fire rates over recent centuries.

\section{Introduction}

Fires are a major source of trace gases and aerosols to the atmosphere (Andreae and Merlet, 2001; Monks et al., 2009). They impact the majority of identified radiative forcing components (Bowman et al., 2009), thereby regulating climate. Nowadays, fires are routinely monitored from satellites (Arino et al., 2012; Giglio et al., 2003; Roy et al., 2005). Historical reconstructions have been made based on tree ring assessments (Falk et al., 2011; Swetnam and Anderson, 2008), charcoal records (Marlon et al., 2008; Scott and Glasspool, 2006), and using measured concentrations of fire-emitted species in ice cores or snow including black carbon and levoglucosan (Kehrwald et al., 2012; McConnell et al., 2007). Another source of information is stand age structure when considering the most recent decades (Kurz and Apps, 1999). The footprint of these studies is usually 
regional and often focusing on temperate regions, but largescale fire emissions assessments are needed for continental and global scale climate reconstructions and to validate fire modules in vegetation models focusing on longer time frames (Kloster et al., 2010; Pechony and Shindell, 2010; Thonicke et al., 2005).

Until about a decade ago, most atmospheric and climate modelling studies relied on simple assumptions, where current biomass burning rates were scaled with proxies such as population density to go back in time. This yielded preindustrial biomass burning rates that were only a fraction of contemporary rates (Houweling et al., 2008; Lamarque et al., 2010), and slowly increasing emissions over the last century when combined with ancillary data on fire activity (Mieville et al., 2010; Mouillot and Field, 2005). A scaling approach using population density makes intuitive sense because, especially in the tropics, most fires are thought to be humanignited although this has never been systematically assessed. However, it fails to recognize that the link between humans and fire activity is complex, and that increased population density does not necessarily translate into more fire activity.

There are several ways by which humans modify the fire landscape (Archibald et al., 2009; Bowman et al., 2011). First, they introduce fires to landscapes that in a natural state rarely burn due to unfavourable climate conditions, such as in tropical forests where fires are now used in the deforestation process (Aragao and Shimabukuro, 2010). Second, humans often increase the number of ignitions compared to those that occur naturally through lightning strikes, both in temperate and tropical regions (Mollicone et al., 2006; Nepstad et al., 1999). Third, humans change fuel composition and density by introducing grazing or prescribed burning (Fernandes and Botelho, 2003; Savadogo et al., 2007). Finally, they fragment the landscape through land management and road building, often stopping fires that would otherwise (if the fuel bed was continuous) burn larger areas. It is important to realize that the number of ignitions becomes less relevant to total area burned when the fuel bed is continuous.

Needless to say, the link between humans and fire activity is complex (Bowman et al., 2011). Still, it came somewhat as a surprise when new studies on ice core measurements of methane $\left(\mathrm{CH}_{4}\right)$ and carbon monoxide $(\mathrm{CO})$ and their isotopic signature implied that pre-industrial biomass burning rates were similar to or even higher than contemporary levels (Ferretti et al., 2005; Wang et al., 2010), something that was also suggested from the compilation of charcoal measurements (Marlon et al., 2008; Power et al., 2008). The results from these three studies (charcoal, $\mathrm{CO}$, and $\mathrm{CH}_{4}$ ) are shown in Fig. 1 and can be somewhat generalized for the past two millennia (Prentice, 2010): emissions were relatively high until about the 14th century, at which point a downturn occurs in all three datasets. In the 17 th century fire activity increased again and either peaked in the late 19th century (charcoal, $\mathrm{CO})$ or at present $\left(\mathrm{CH}_{4}\right)$.

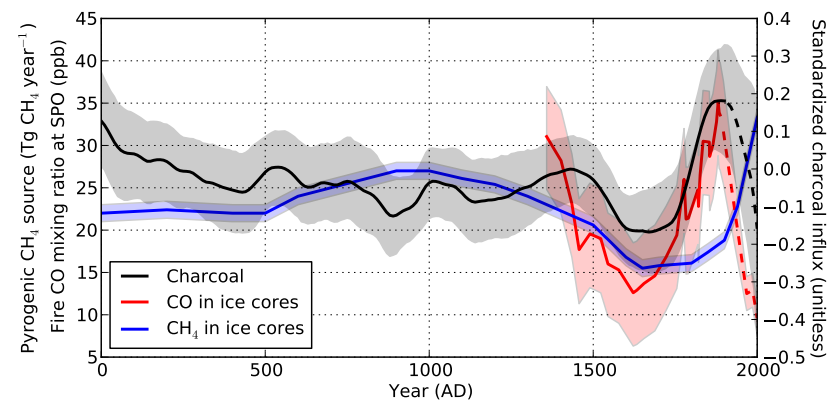

Fig. 1. Variability of biomass burning rates over the last centuries based on a worldwide compilation of charcoal records (Marlon et al., 2008), CO mixing ratios from fires using $\mathrm{CO}$ concentration measurements at the South Pole (SPO), its isotopic signature, and a mass balance model (Wang et al., 2010), and a similar approach but based on $\mathrm{CH}_{4}$ (Ferretti et al., 2005). The $\mathrm{CO}$ ice core data ended in 1897 but was extended (dashed line) by Wang et al. (2010) to present-day using firn samples (1968 and 1986) as well as modelling (year 2000). Shaded areas indicate reported uncertainty. Note that the datasets have different footprints and that absolute values cannot be compared directly.

Several hypotheses have been put forward to explain the observed variability, focusing on climate and humans. The charcoal record shows a decreasing trend over the first millennium, possibly as a result of global cooling (Marlon et al., 2008). In addition, the low values during the 16th and 17th century coincide with the Little Ice Age, also hinting at the importance of climate in driving global fire rates (Power et al., 2013). The downturn in the 15th century has also been linked to the arrival of Europeans in the tropics, especially in South America (Ferretti et al., 2005). They introduced diseases and decimated the local population that was probably accustomed to using fire, thus decreasing fire activity. The increase in the 19th century is most often linked to land clearance from European settlement in temperate regions, while the downturn in the 20th century may be linked to increasing portions of the landscape occupied by intensive land management with reduced fuel loads and fragmented fuel beds (Prentice, 2010).

While the general patterns agree, there are substantial differences between the $\mathrm{CH}_{4}, \mathrm{CO}$, and charcoal datasets. This is not surprising, because the footprint is rather different due to varying lifetimes of $\mathrm{CH}_{4}$ (about a decade, the ice core measurements are thus impacted by all biomass burning regions worldwide) and $\mathrm{CO}$ (about two months, thus more impacted by the Southern than the Northern Hemisphere). In addition, the charcoal database has much better coverage in temperate regions than in the tropics, where the majority of fire emissions take place. A key discrepancy is that the $\mathrm{CH}_{4}$ data (Ferretti et al., 2005), which has been confirmed by Mischler et al. (2009), supports the relatively high values in the first millennium, but does not support the second peak around 1900 AD. Instead, it peaks in current times with higher rates 
than in the previous $2000 \mathrm{yr}$. Firn air samples focusing on recent decades also find an increasing trend, both in the Northern (Wang et al., 2012) and Southern (Assonov et al., 2007) Hemisphere. These findings are contradictory to the results of Marlon et al. (2008) and Wang et al. (2010). Even though discrepancies in the latter part of the record exist, there are strong indications of substantial variations and higher-thanexpected emissions in the pre-industrial era.

In this paper we aimed to understand what these ice core measurements actually mean for the fire landscape, neglecting the potential of additional sources such as charcoal production or changes due to atmospheric transport and chemistry to account for some of the discrepancies. We focused on the most recent results from Wang et al. (2010) and performed several steps to understand what mixing ratio measurements in a remote location can say about fire activity in all of the Southern Hemisphere, or even globally. We specifically investigated which scenario of fire return times and carbon emissions was needed in the Southern Hemisphere to support a quadrupling of $\mathrm{CO}$ mixing ratios from fires at South Pole station (SPO), as reported by Wang et al. (2010).

Our approach used remote sensing data from fires in combination with biogeochemical and chemical transport modelling to better understand how contemporary fires contribute to $\mathrm{CO}$ mixing ratios at SPO. In addition, we tested how sensitive savanna fire emissions are to changes in fire return time, and used scenarios for human-induced fires (such as fuelwood burning) to estimate emissions from these fires back in time. We focused on the $1400 \mathrm{AD}$-present time period which overlaps with the CO record from Wang et al. (2010). To some degree, our results are applicable to earlier time periods as well, although we do not account for changes over time in atmospheric transport and chemistry that could affect our conclusions.

\section{Methods}

\subsection{Introduction}

Our analysis consisted of three parts. First, we built a fire emissions climatology based on $14 \mathrm{yr}$ of recent fire activity from the Global Fire Emissions Database (GFED3; Giglio et al., 2010; van der Werf et al., 2010). These emissions were partitioned into five fire sources: deforestation, forest, nonforest, tropical peat, and fuelwood burning. This analysis was for a large part driven by satellite data of the land surface, with burned area and vegetation productivity as main input datasets. We then input the emissions climatology into the TM5 chemical transport model (Krol et al., 2005) to estimate the contribution of these five fire emission sources to $\mathrm{CO}$ mixing ratios at SPO. TM5 was driven by present-day $\mathrm{OH}$ concentrations and atmospheric transport patterns. In the second part of our analysis, we estimated historical fire emissions since $1400 \mathrm{AD}$ assuming that the human-driven fire sources (deforestation, tropical peat, and fuelwood) were population-density dependent. This step was driven mainly by the GFED fire emissions estimates partitioned into different sources and reconstructions of population densities. And finally, we built a simple model that could mimic GFED emissions estimates for savanna areas to estimate the sensitivity of savanna fire emissions to changes in fire return time (i.e., the time between consecutive fires for a given area). The main input datasets for this step were temperature, precipitation, and satellite-derived burned area as used in GFED. These three steps are described below in more detail.

\subsection{Global Fire Emissions Database (GFED) and chemical transport modelling}

GFED3 fire emissions are calculated by taking the product of burned area, fuel loads, combustion completeness, and emission factors (von Danckelman, 1884; Seiler and Crutzen, 1980) at a spatial and temporal resolution of $0.5^{\circ}$ and one month, respectively. Burned area estimates were from Giglio et al. (2010, 2009) based mostly on Moderate Resolution Imaging Spectroradiometer (MODIS) satellite data. Fuel loads and combustion completeness were calculated with the Carnegie-Ames-Stanford-Approach (CASA) biogeochemical model (van der Werf et al., 2010). Total fire emissions were partitioned in various sources, including deforestation, forest, savanna, woodland, agricultural waste burning, and tropical peat fires using a land-cover classification and a metric based on the persistence of active fire detections (van der Werf et al., 2010). The resulting carbon emissions were converted to trace gas emissions estimates based on an emission factor literature survey by Andreae and Merlet (2001) with annual updates. Here we combined several sources occurring in low tree cover density areas (savanna, woodland, and agricultural waste burning) into one class, named non-forest. GFED does not include emissions from the burning of fuelwood; these were taken from the Emissions Database for Global Atmospheric Research (EDGAR) version 4.1 (http://edgar.jrc.ec.europa.eu/; Olivier et al., 2011) with the methodology partly based on the work of Yevich and Logan (2003). Besides fuelwood burning this source also includes smaller contributions from agricultural residues and dung burning. The burning of agricultural waste in the field is partly captured by GFED.

We used the TM5 chemical transport model (Krol et al., 2005) to simulate the atmospheric transport and chemical breakdown of CO from GFED fire emissions (climatology of $14 \mathrm{yr}$ of emissions data) as well as other sources such as fossil fuel emissions and methane oxidation. TM5 was driven by European Centre for Medium-Range Weather Forecasts (ECMWF) meteorological fields at 3-hourly resolution to transport $\mathrm{CO}$ through the atmosphere by advection, wet and dry convection, and vertical diffusion in a mass-conserving approach. Once in the atmosphere, $\mathrm{CO}$ was removed by the $\mathrm{CO}+\mathrm{OH}$ chemical reaction using rates as in Huijnen 
et al. (2010), with monthly mean $\mathrm{OH}$ prescribed from the Spivakovsky et al. (2000) spatial distribution scaled with a factor of 0.92 to yield better correspondence with observed methylchloroform (Huijnen et al., 2010). Additionally, CO was removed at the surface by dry deposition as described in Hooghiemstra et al. (2011). We used the average CO mole fractions at SPO of the simulations using 2002-2007 meteorology in our simulations, thus averaging out interannual variations in weather. Note that past changes in atmospheric circulation and $\mathrm{OH}$ concentrations relative to this period were not included in our analysis.

We performed so-called tagged tracer runs, wherein we introduced different $\mathrm{CO}$ source categories by geographic region as separate tracers to assess their contribution to $\mathrm{CO}$ mixing ratios at SPO where ice cores have been taken. The seasonal cycle in fire emissions was based on GFED, while we assumed that fuelwood emissions had no seasonal cycle because the majority of fuelwood combustion is for cooking purposes which is not thought to vary much over the course of a year.

\subsection{Fire emissions since $1400 \mathrm{AD}$}

To reconstruct fire emissions since $1400 \mathrm{AD}$, we scaled the fire source categories that are driven by humans (deforestation, tropical peat, and fuelwood) back in time using rural population density maps for each century (Klein Goldewijk et al., 2010). In our analysis we did not account for charcoal production and burning that may have been more important in the past than it is now. During the production and burning process it may release about $450 \mathrm{~g} \mathrm{CO}$ per kg dry matter burned (Akagi et al., 2011), 8 times more than savanna fires do. Its magnitude is uncertain but likely to be in the order of $10 \%$ of total contemporary biomass burning $\mathrm{CO}$ emissions. This number was derived from combining $\mathrm{CH}_{4}$ estimates from Sapart et al. (2012) with emission factors from Akagi et al. (2011).

To scale fuelwood emissions with population densities, we assumed that per-capita fuelwood use was constant over time. The link between population density and tropical peat fires was demonstrated by Field et al. (2009) and independent deforestation assessments support our approach for fires in deforestation regions. For example, about $80 \%$ of the Legal Amazon was still forested up to 1958 when road construction began (the Belém-Brasilía and later the Cuiabá-Porto Velho highway). Clearly, tropical deforestation has happened in the centuries before and our approach cannot properly account for the dynamic deforestation process, for example related to feedbacks between fire and deforestation (Cochrane and Barber, 2009; Balch et al., 2008). However, if deforestation has happened continuously then deforestation rates must have been much lower than the current rates of about $0.5 \% \mathrm{yr}^{-1}$ (Hansen et al., 2008). As an alternative, we also explored scenarios where rates were high in earlier centuries after which the forest could regrow in subsequent periods.
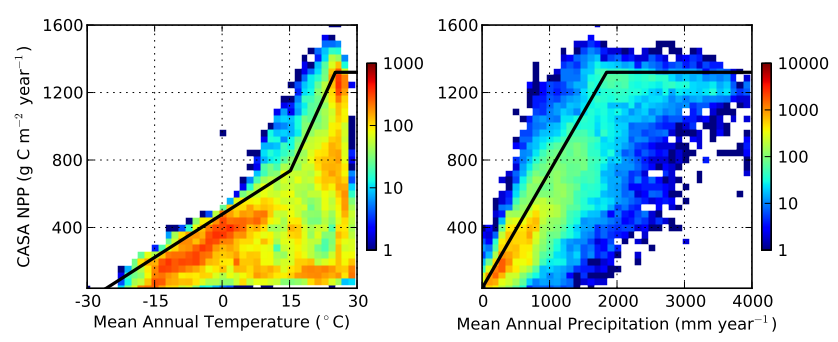

Fig. 2. CASA-predicted net primary production (NPP) against mean annual temperature (MAT, left) and precipitation (MAP, right) for all terrestrial $0.5^{\circ}$ grid cells. The color scale indicates the number of $0.5^{\circ}$ grid cells corresponding to NPP, MAP, and MAT bins. Black lines correspond roughly to 90 th percentiles.

We kept the other sources constant for this exercise. This does not mean that humans do not influence fire activity in savannas and forests, but that we cannot say a priori whether they increase or decrease fire activity because of opposing effects.

\subsection{Sensitivity of savanna fire emissions to changes in fire return time}

To estimate how sensitive $\mathrm{CO}$ emissions in savannas are to changes in fire return time we built a simple fuel accumulation model. In savanna ecosystems, the grass layer is the main source of fuel. These grasses build up during the wet season and become susceptible to fire during the dry season. In arid and medium rainfall areas, it takes several wet seasons before the fuel layer has fully built up, partly related to slowly decomposing fuel components from trees such as coarse woody debris. One approach to simulate this behaviour is to use the Olson equation (Cook, 2003; Olson, 1963):

Fuel $=\frac{\text { Litterfall }}{k}\left(1-e^{-k t}\right)$,

where $k$ is the turnover rate of litter and $t$ the time step, in our case in years. To estimate litterfall, we plotted net primary production (NPP) from the CASA model used in GFED against mean annual precipitation (MAP; Huffman et al., 2009) and mean annual temperature (MAT; Hansen et al., 1999) based on the 1997-2010 time period overlapping with the GFED time period (Fig. 2). We then fitted lines roughly corresponding with the 90th percentiles for $100 \mathrm{~mm} \mathrm{yr}^{-1} \mathrm{MAP}$ or $1^{\circ} \mathrm{C}$ bins (black lines in Fig. 2). The reason to model NPP instead of taking the values derived from satellite-based vegetation indices as done in CASA was to minimize the effect of humans on NPP; in many regions humans have modified the landscape, lowering grid cell average NPP.

Modelled NPP maps were then based on the combination of MAP and MAT and the scaling factors derived from the black lines in Fig. 2, with the lowest factor defining NPP. The resulting NPP map and the difference with CASA NPP 

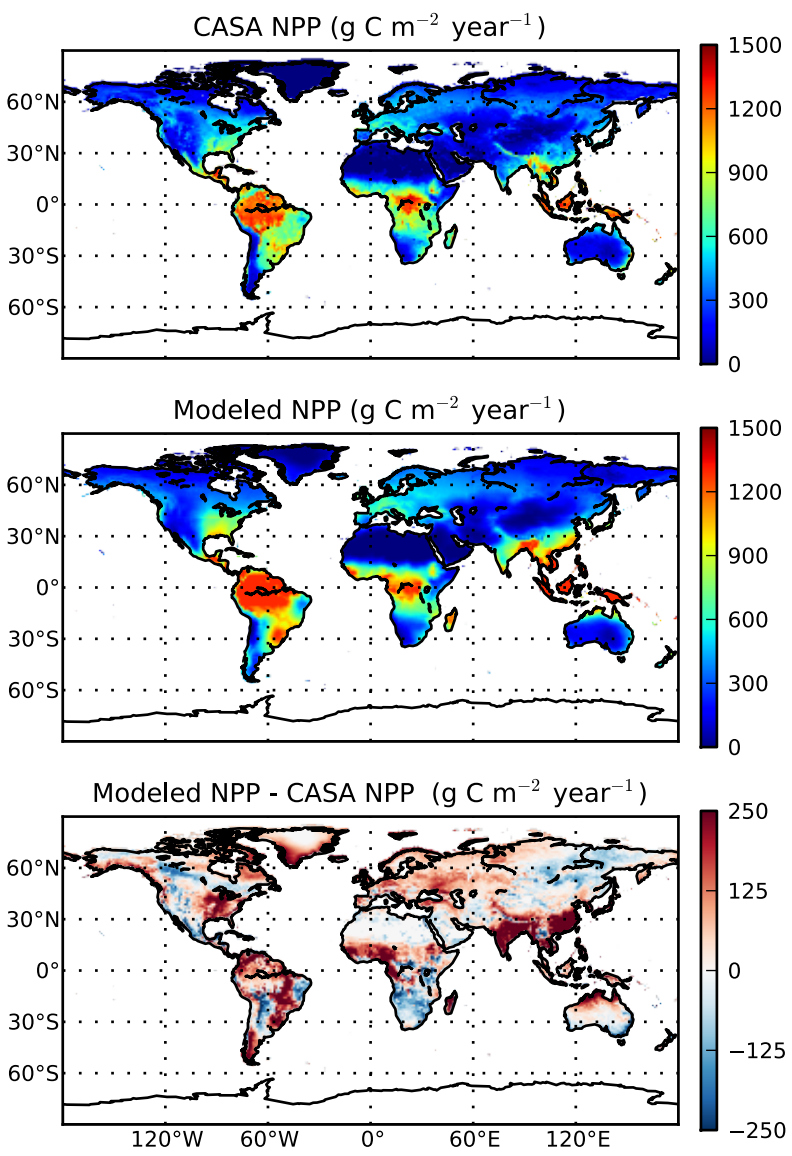

Fig. 3. NPP derived from the CASA model (top), the MAP and MAT based model (middle), and the absolute difference between the two approaches (bottom).

are shown in Fig. 3 as maps and in Fig. 4 as 2-dimensional histograms. The relations hold reasonably well, with largest discrepancies over populated areas (India, China, and West Africa) possibly due to the dependence of CASA NPP on satellite-derived vegetation indices. In addition, our approach underestimated the productivity in most of Southern Africa. To test how sensitive our results were to the newly developed NPP map, we also performed a run using CASA NPP that will be described in the uncertainty section (Sect. 4.4). Litterfall was then assumed to be $55 \%$ to account for NPP allocation to roots, in line with the original CASA scheme for grass-dominated ecosystems.

To estimate the turnover rate of litter, we followed the CASA structure and used a temperature and moisture scalar that would lower a set turnover rate when temperature or moisture were limiting. The highest turnover rate was set to 10 months after several iterations to best match CASAGFED results (see below) and the scalars followed a $Q_{10}$ approach (defining the rate of change as a consequence of changing ambient conditions). For temperature we used a $Q_{10}$ of 1.5 (so litter turnover rate increases by $50 \%$ for each increase in temperature of $10^{\circ} \mathrm{C}$ ) with a maximum of 1 when
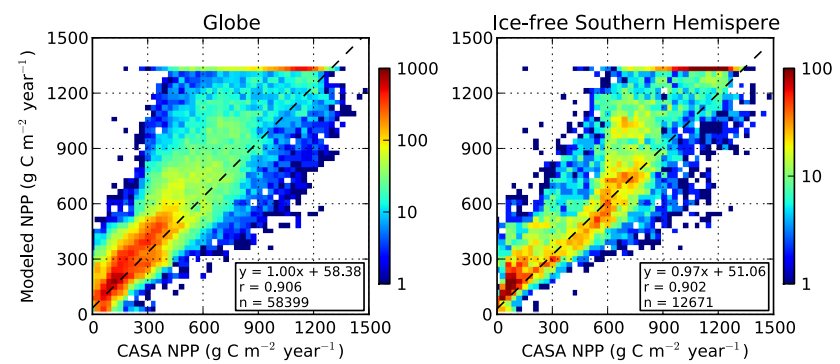

Fig. 4. Two-dimensional histograms of NPP derived from the simple MAP and MAT-dependent variables versus CASA NPP for all terrestrial $0.5^{\circ}$ grid cells globally (left panel) and the Southern Hemisphere (right panel). The color scale indicates the number of $0.5^{\circ}$ grid cells corresponding to NPP bins. Least squares linear regression lines are shown in black. The modelled emissions were capped at $1300 \mathrm{~g} \mathrm{C} \mathrm{m}^{-2} \mathrm{yr}^{-1}$.

temperature was $30^{\circ} \mathrm{C}$, and for precipitation we used a similar scalar but it reached its maximum of 1 at rainfall rates of $2000 \mathrm{~mm} \mathrm{yr}^{-1}$ MAP. The combined scalar was based on the multiplication of the temperature and moisture scalar and shown in the top panel of Fig. 5, while the inverse of this scalar is the mean litter turnover rate in years and shown in the middle panel. Combining NPP and $k$ using the Olson equation yields the amount of litter (to which we will refer as fuel) when NPP and respiration are in equilibrium (bottom panel of Fig. 5). Our approach using the Olson equation may be biased towards woody savannas where litterfall from trees plays an important role. This part of the fuel decomposes more slowly than litter from grasses, so we also tested the sensitivity of our results to the degree to which fuels carry over to following years. In grassland-dominated savannas the amount of carry-over may be limited so that fuels do not change much from year to year, which is further discussed in Sect. 4.4.

As an example of how the model behaves, we plotted fuel build-up for a typical productive savanna site with $800 \mathrm{~g} \mathrm{C} \mathrm{m}^{-2} \mathrm{yr}^{-1}$ of NPP in Fig. 6. In our approach this corresponded to $440 \mathrm{~g} \mathrm{C} \mathrm{m}^{-2} \mathrm{yr}^{-1}$ litterfall, and with a turnover rate of 10 months the maximum fuel load was $528 \mathrm{~g} \mathrm{C} \mathrm{m}^{-2} \mathrm{yr}^{-1}(440 /(10 / 12))$ that was reached after about $5 \mathrm{yr}$. For areas with slower turnover rates it takes longer for the fuel to reach its maximum. Figure 6 also shows mean annual fire emissions as a function of fire return time. Only for the case of fire return times exceeding the number of years required to reach equilibrium will a doubling of fire activity (halving fire return times) lead to a doubling of emissions. For example, while halving the fire return interval from 10 to $5 \mathrm{yr}$ boosts emissions by about $100 \%$ in our example, halving it from 2 to $1 \mathrm{yr}$ adds $70 \%$.

While simple, this model captured about $80 \%$ of the variability in NPP as predicted by CASA (depending on the domain, see Fig. 4). More importantly, when the model was combined with GFED burned area it captured about $86 \%$ of 

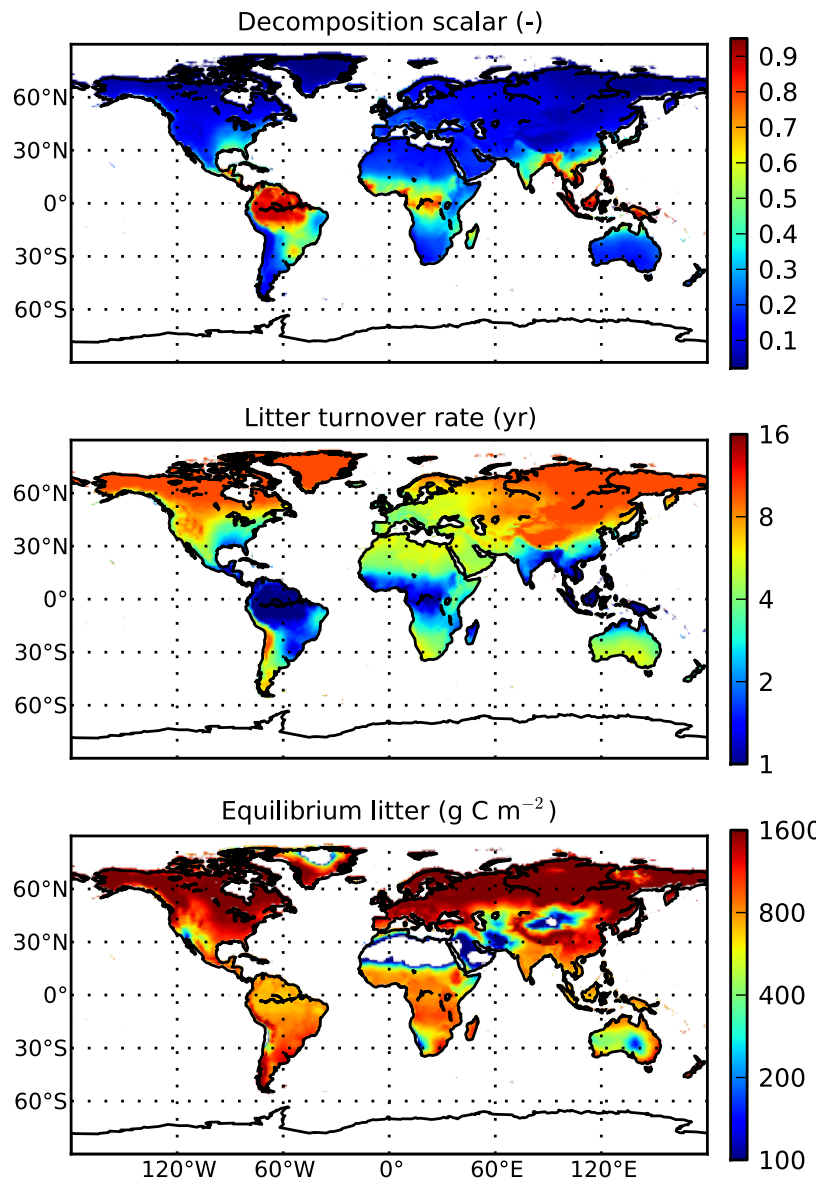

Fig. 5. Decomposition scalars based on a temperature and moisture scalar (top), turnover rates based on the inverse of the decomposition scalar (middle), and equilibrium litter (or fuel) combining NPP and turnover rates (bottom).

the variability in savanna fire emissions (Fig. 7). Lowering or boosting fuel turnover rates $(k)$ lowered the fit. Emissions from the simple model were derived by inverting the mean fraction of each grid cell that burned (averaged over 19972010), rounding this, and combining it with the fuel loads as predicted by the Olson equation as a function of time since last fire. For example, if the satellite data indicated that on average $30 \%$ of the $0.5^{\circ}$ grid cell burned in a year we assumed it had a fire return interval of $3.33 \mathrm{yr}$. By rounding this number and combining it with the fuel load since last fire -in this case after $3 \mathrm{yr}$ - we could calculate mean annual emissions as shown in Fig. 8. In this scaling approach we did not account for changes in emissions due to other impacts. For example, changing climate and vegetation composition have influenced fire emissions over time, but likely to a smaller degree than the changing fire frequencies.

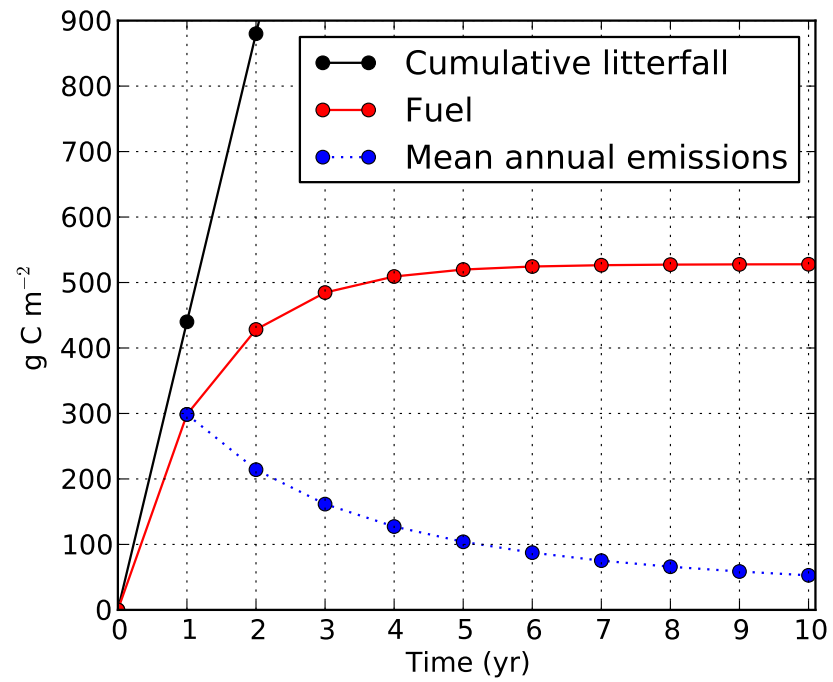

Fig. 6. Litterfall, fuel build-up, and corresponding mean annual emissions as predicted by the Olson equation (Eq. 1) for a site with $800 \mathrm{~g} \mathrm{C} \mathrm{m}^{-2} \mathrm{yr}^{-1}$ of NPP of which $55 \%$ is available to grow aboveground biomass. The graph shows the first ten years after a fire, and we assumed no aboveground biomass was left on the site after the fire that burned in year zero. Mean annual emissions were calculated by dividing the amount of fuel in that year (red dot) by the number of years since fire. After a fire in a given year (which would correspond to the fire return time), the amount of fuel would be reset to zero.
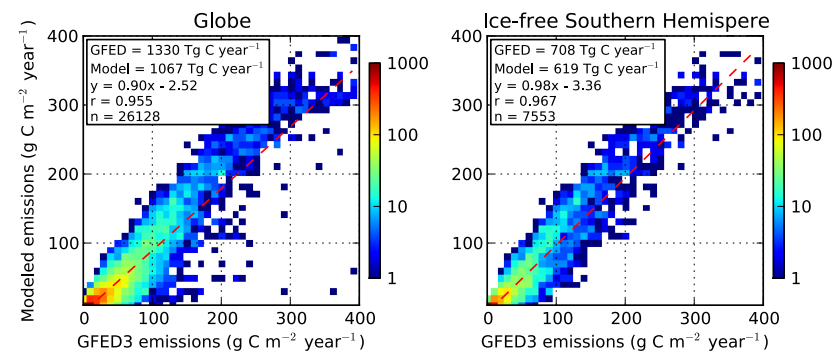

Fig. 7. Modelled emissions based on satellite-derived fire return times and the Olson equation versus GFED3 emissions for all terrestrial $0.5^{\circ} \times 0.5^{\circ}$ grid cells (left) and those in the Southern Hemisphere (right). The color scale indicates the number of $0.5^{\circ}$ grid cells corresponding to emissions bins. Data is averaged over 19972010. Least squares linear regression lines are shown in red.

\section{Results}

\subsection{Present day emissions and chemical transport}

Our simulations indicated that the $3.1 \mathrm{PgC} \mathrm{yr}^{-1}$ $\left(P=\right.$ peta $\left.=10^{15}\right)$ emitted due to landscape fires and fuelwood combustion, of which $512 \mathrm{Tg} \mathrm{CO} \mathrm{yr}^{-1}\left(T=\right.$ tera $\left.=10^{12}\right)$ was emitted as $\mathrm{CO}$, contributed to almost $7 \mathrm{ppb} \mathrm{CO}$ at SPO over the last decade (Table 1). Due to the lifetime of CO of about 2 months, regions close to SPO contributed more strongly than regions further away. As an example, while 
Table 1. GFED3 emissions estimates of carbon (C) and carbon monoxide (CO) for various regions and sources, the resulting $\mathrm{CO}$ mixing ratio at $\mathrm{SPO}$, and the relative ratio between $\mathrm{C}$ and $\mathrm{CO}$ emissions and SPO mixing ratios as a measure of how much the various sources contribute to contemporary SPO mixing ratios. $\mathrm{Tg}=10^{12} \mathrm{~g}, \mathrm{Pg}=10^{15} \mathrm{~g}$. See also Fig. 9.

\begin{tabular}{|c|c|c|c|c|c|c|c|}
\hline & \multirow[b]{2}{*}{ Region } & \multicolumn{5}{|c|}{ Fire type } & \multirow[b]{2}{*}{ Total } \\
\hline & & Deforestation & Forest & Non-forest & Tropical peat & Fuelwood & \\
\hline \multirow{6}{*}{ 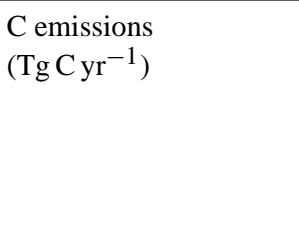 } & Northern Hemisphere & 147 & 202 & 577 & 12 & 825 & 1763 \\
\hline & Southern Hemisphere America & 155 & 23 & 124 & - & 26 & 328 \\
\hline & Southern Hemisphere Africa & 27 & 52 & 537 & - & 83 & 699 \\
\hline & Southern Hemisphere Asia & 45 & 5 & 6 & 88 & 30 & 174 \\
\hline & Australia & 2 & 12 & 117 & - & 3 & 134 \\
\hline & Globe & 375 & 294 & 1362 & 100 & 967 & 3097 \\
\hline \multirow{6}{*}{$\begin{array}{l}\mathrm{CO} \text { emissions } \\
\left(\mathrm{TgCO} \mathrm{yr}^{-1}\right)\end{array}$} & Northern Hemisphere & 30.8 & 44.3 & 73.9 & 4.4 & 134.1 & 287.6 \\
\hline & Southern Hemisphere America & 32.5 & 5.1 & 15.9 & - & 4.2 & 57.7 \\
\hline & Southern Hemisphere Africa & 5.6 & 11.5 & 68.8 & - & 13.4 & 99.3 \\
\hline & Southern Hemisphere Asia & 9.4 & 1.2 & 0.8 & 32.3 & 4.9 & 48.6 \\
\hline & Australia & 0.5 & 2.6 & 15.0 & - & 0.4 & 18.5 \\
\hline & Globe & 78.8 & 64.7 & 174.4 & 36.7 & 157.1 & 511.7 \\
\hline \multirow{6}{*}{$\begin{array}{l}\mathrm{CO} \text { mix. ratio } \\
(\mathrm{ppb} @ \mathrm{SPO})\end{array}$} & Northern Hemisphere & 0.22 & 0.11 & 0.49 & 0.05 & 0.60 & 1.47 \\
\hline & Southern Hemisphere America & 0.98 & 0.20 & 0.69 & - & 0.27 & 2.13 \\
\hline & Southern Hemisphere Africa & 0.10 & 0.17 & 1.31 & - & 0.42 & 1.99 \\
\hline & Southern Hemisphere Asia & 0.09 & 0.01 & 0.01 & 0.26 & 0.09 & 0.45 \\
\hline & Australia & 0.01 & 0.24 & 0.46 & - & 0.05 & 0.77 \\
\hline & Globe & 1.39 & 0.74 & 2.96 & 0.32 & 1.42 & 6.82 \\
\hline \multirow{6}{*}{$\begin{array}{l}\text { Efficiency } \\
\text { (ppb@SPO per Pg C) }\end{array}$} & Northern Hemisphere & 1.49 & 0.54 & 0.85 & 4.60 & 0.72 & 0.83 \\
\hline & Southern Hemisphere America & 6.34 & 8.74 & 5.52 & - & 10.31 & 6.51 \\
\hline & Southern Hemisphere Africa & 3.62 & 3.26 & 2.44 & - & 5.03 & 2.85 \\
\hline & Southern Hemisphere Asia & 1.96 & 1.86 & 1.19 & 2.98 & 2.88 & 2.60 \\
\hline & Australia & 3.95 & 20.71 & 3.96 & - & 19.86 & 5.75 \\
\hline & Globe & 3.71 & 2.51 & 2.17 & 3.17 & 1.47 & 2.20 \\
\hline \multirow{6}{*}{$\begin{array}{l}\text { Efficiency } \\
\text { (ppb@SPO per Pg CO) }\end{array}$} & Northern Hemisphere & 7.1 & 2.5 & 6.6 & 12.5 & 4.4 & 5.1 \\
\hline & Southern Hemisphere America & 30.2 & 39.7 & 43.1 & - & 63.4 & 37.0 \\
\hline & Southern Hemisphere Africa & 17.2 & 14.8 & 19.1 & - & 31.0 & 20.1 \\
\hline & Southern Hemisphere Asia & 9.3 & 8.5 & 9.3 & 8.1 & 17.7 & 9.3 \\
\hline & Australia & 18.8 & 94.2 & 30.9 & - & 122.2 & 41.6 \\
\hline & Globe & 17.7 & 11.4 & 17.0 & 8.6 & 9.0 & 13.3 \\
\hline
\end{tabular}

over $50 \%$ of global fire $\mathrm{CO}$ emissions came from the Northern Hemisphere (mostly due to fuelwood combustion), these fires contributed only $1.5 \mathrm{ppb}$ CO to SPO. Southern Hemisphere America by itself was more important than all of the Northern Hemisphere for SPO CO mixing ratios with over $2 \mathrm{ppb} \mathrm{CO}$, even though its global share of $\mathrm{CO}$ fire emissions was just over $10 \%$ (Fig. 9).

Also within the Southern Hemisphere there was substantial variability in the efficiency of transport from the various regions to SPO. Southern Hemisphere America, Africa, Asia, and Australia contributed 11, 19, 9, and $4 \%$ of total global $\mathrm{CO}$ fire emissions, respectively. The corresponding contribution at SPO, however, was 31, 29, 7, and $11 \%$ (Table 1). In other words, emissions from South America and Australia were about twice as efficient in impacting SPO CO mixing ratios as Africa. Sources that were relatively close to the SPO impacted SPO most. These included temperate forest fires and fuelwood burning mostly in Australia and South America. These fires burned predominantly in the southern part of the continents. However, these sources were relatively small so although they were efficient (high SPO mixing ratio to emissions ratio), they are at current rates not crucial for SPO $\mathrm{CO}$ mixing ratios.

In Table 1 we also included the carbon emissions from which $\mathrm{CO}$ emissions were derived, as well as the efficiency with regard to carbon emissions. The conversion of $\mathrm{C}$ to $\mathrm{CO}$ was based on the average of emission factor measurements (Andreae and Merlet, 2001). The number of studies from which the average was drawn varied between fire types and the representativeness is still uncertain (van Leeuwen and van der Werf, 2011), but in general fire types with a large smouldering component (e.g., deforestation, peat, forest fires) have higher $\mathrm{CO}$ emission factors than those fires 

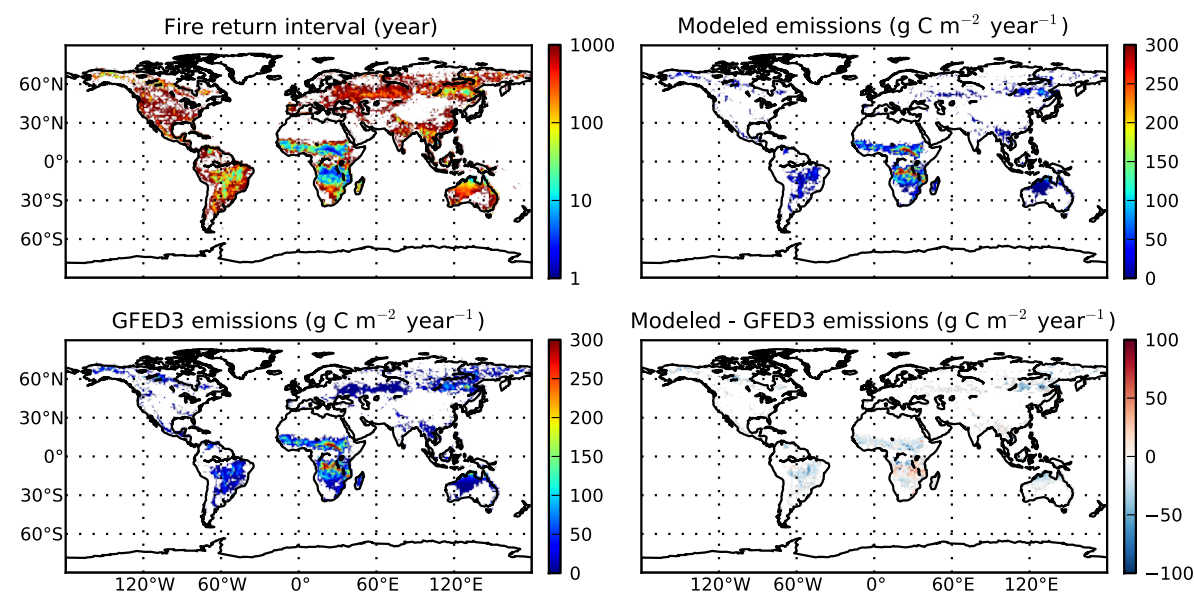

Fig. 8. Fire return intervals based on inverting the mean fraction of each grid cell that burned over 1997-2010 (top left), modelled emissions based on the fire return intervals and the Olson equation (top right), GFED3 emissions (bottom left), and the difference between modelled and GFED3 emissions (bottom right).

that burn predominantly in the flaming phase (e.g. savanna fires).

Due to the variation in emission factors, the efficiency for $\mathrm{C}$ to SPO was different than that for CO (Table 1). Specifically, the efficiency for fire sources with a high $\mathrm{CO}$ emission factor (deforestation, forest, and especially peat) measured per unit $\mathrm{C}$ was higher than measured per unit $\mathrm{CO}$. For example, when we compare non-forest and peat fires in Southern Hemisphere Asia then each unit $\mathrm{CO}$ burned in these two fire types elevated $\mathrm{CO}$ mixing ratios with about the same amount, but when considering units of $\mathrm{C}$ instead of $\mathrm{CO}$ then the peat areas were almost three times more "efficient" than the grasslands, because they emitted almost three times as much $\mathrm{CO}$ per unit carbon compared to non-forests. Conversely, to explain a certain amount of $\mathrm{CO}$ one must have three times more grassland burning than peat burning. Since $\mathrm{C}$ is a more accepted unit for quantifying fire emissions and because it is directly related to dry biomass we will focus the discussion on the efficiency per unit $\mathrm{C}$.

\subsection{Fire emissions reconstructions: fire sources driven by humans}

The largest changes in population density occurred during the last century, which is reflected in emission estimates for the human-driven sources fuelwood, tropical peat, and deforestation (Fig. 10). Combining these time-dependent humandriven sources with constant emissions in forests and nonforests, emissions would have been roughly $50 \%$ of current rates with the largest drop due to lower fuelwood burning rates in the Northern Hemisphere.

Combining the reconstructed emissions with present-day chemical transport showed that the decrease in SPO CO mixing ratios was smaller than the estimated decrease in fire emissions (Fig. 10) because the largest emissions decreases

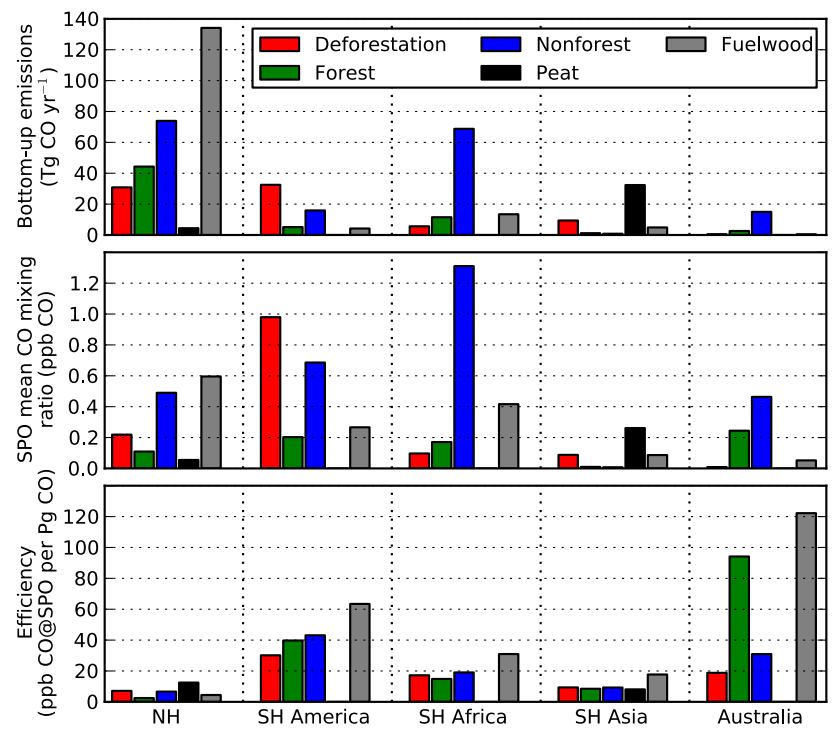

Fig. 9. GFED3 $\mathrm{CO}$ emissions estimates for various regions and sources (top panel), the resulting $\mathrm{CO}$ mixing ratio at SPO (middle panel), and the ratio between emissions and SPO mixing ratios as a measure of how much the various sources contribute to SPO mixing ratios, relatively. $\mathrm{NH}$ is Northern Hemisphere, $\mathrm{SH}$ is Southern Hemisphere. See also Table 1.

in our rural population scaling approach occurred far away from the South Pole. The model estimated fire SPO CO mixing ratios in $1400 \mathrm{AD}$ were about $35 \%$ below present-day, with the largest drop due to decreased deforestation in Southern Hemisphere America. 
Table 2. Modelled non-forest emissions and resulting CO mixing ratios at SPO for various uniformly applied fire return times (FRT) applied to all Southern Hemisphere areas not occupied by forest. The current mean fire return time is about $32 \mathrm{yr}$ (indicated in italic), but with substantial regional variability.

\begin{tabular}{|c|c|c|c|c|c|c|c|c|c|c|}
\hline \multirow[b]{2}{*}{ FRT $(y r)$} & \multicolumn{5}{|c|}{ Emissions ( $\mathrm{Tg} \mathrm{CO}_{\mathrm{yr}^{-1}}$ ) } & \multicolumn{5}{|c|}{ SPO mean $\mathrm{CO}$ mixing ratio (ppb) } \\
\hline & S-Ame & S-Afr & S-Asia & Austr & All SH & S-Ame & S-Afr & S-Asia & Austr & All SH \\
\hline 1 & 390 & 312 & 11 & 167 & 880 & 16.82 & 5.95 & 0.11 & 5.16 & 28.03 \\
\hline 2 & 315 & 258 & 8 & 142 & 724 & 13.56 & 4.92 & 0.08 & 4.40 & 22.96 \\
\hline 4 & 221 & 187 & 5 & 108 & 521 & 9.53 & 3.56 & 0.05 & 3.34 & 16.49 \\
\hline 8 & 134 & 114 & 3 & 70 & 322 & 5.78 & 2.18 & 0.03 & 2.18 & 10.17 \\
\hline 16 & 73 & 61 & 1 & 39 & 174 & 3.14 & 1.16 & 0.01 & 1.22 & 5.53 \\
\hline 32 & 37 & 31 & 1 & 20 & 89 & 1.60 & 0.58 & 0.01 & 0.62 & 2.82 \\
\hline 64 & 19 & 15 & 0 & 10 & 44 & 0.80 & 0.29 & 0.00 & 0.31 & 1.41 \\
\hline 128 & 9 & 8 & 0 & 5 & 22 & 0.40 & 0.15 & 0.00 & 0.16 & 0.70 \\
\hline
\end{tabular}

\subsection{Sensitivity of savanna fire emissions to changes in fire return time}

If all of the Southern Hemisphere non-forest area could and would burn annually, emissions would be about 7.0 $\mathrm{Pg} \mathrm{C} \mathrm{yr}^{-1}$ with about $880 \mathrm{Tg} \mathrm{CO} \mathrm{yr}^{-1}$ emitted as CO. Our model indicated that these fires would elevate SPO CO mixing ratios by about $28 \mathrm{ppb}$ compared to a Southern Hemisphere without savanna fires (Table 2). The current mean fire return time of these regions is about $32 \mathrm{yr}$, corresponding to $2.5 \mathrm{ppb} \mathrm{CO}$ with the current fire distribution (Table 1), or $2.8 \mathrm{ppb} \mathrm{CO}$ with a uniformly applied fire return time of $32 \mathrm{yr}$ (Table 2). The reason for the $0.3 \mathrm{ppb} \mathrm{CO}$ difference is that with the current fire distribution several savanna regions experience fire return times well below the time required to reach maximum fuel build-up (Fig. 6). Repeated halving of fire return times (doubling fire frequencies) from current rates led to an almost doubling of emissions as long as the fire return time was longer than the time required to reach fuel equilibrium (Figs. 6 and 11). This is reflected in Table 2 where emissions almost doubled when fire return intervals decreased from 32 to 16 yr. Further halvings increased emissions by $85,62,39$, and $21 \%$ for changes from 16 to 8 , 8 to 4,4 to 2 , and 2 to $1 \mathrm{yr}$, respectively. The message here is that although more frequent burning always leads to an increase in emissions, the rate of increase is reduced when fire return times are lower than the time required to reach maximum fuel build-up.

\section{Discussion}

\subsection{Introduction}

Our results indicate that while all fires impact SPO CO mixing ratios, there is large variability between different fire sources and regions in the ratio between burned biomass and corresponding SPO CO mixing ratio. Within the Southern Hemisphere, we calculated that fire emissions from South
America and Australia may have impacted SPO CO mixing ratios about twice as much per unit $\mathrm{CO}$ combusted as emissions from Africa and Southern Hemisphere Asia; fire sources in the Southern Hemisphere closer to the SPO (for example, temperate forest fires and fuelwood burning) had a more pronounced influence than non-forest burning; and when considering carbon emissions instead of $\mathrm{CO}$ emissions then the fire sources that burn predominantly in the smouldering phase such as peat fires were more important than fires burning mostly in the flaming phase. Similar patterns have been observed by other studies based on different atmospheric transport models (Kaminski et al., 1996; Krinner and Genthon, 2003). Besides proximity to the Southern Hemisphere storm tracks that bring air to SPO relatively quickly, the blocking of westward transport due to the Andes and subsequent southward funnelling of air masses during the fire season may increase the efficiency of South American fires compared to regions along the same latitude.

Due to these large differences in "efficiencies" (the elevation of SPO CO mixing ratios per unit carbon combusted) that varied between $0.54 \mathrm{ppb} \mathrm{CO}$ delivered to SPO per Pg C burned for forest fires in the Northern Hemisphere to over 20 ppb CO per Pg C for forest fires in Australia, one could in principle envision scenarios where Southern Hemisphere biomass burning rates decreased while their contribution to SPO CO mixing ratios increased, or vice versa. However, this would require a large boost in the sources that are the most efficient, but these are also a relatively small fraction of total fire emissions. It is not likely that they have been orders of magnitude higher in the past.

We calculated that the about $3.1 \mathrm{PgC} \mathrm{yr}^{-1}$ or $512 \mathrm{TgCO} \mathrm{yr}^{-1}$ emitted from contemporary fires elevated SPO $\mathrm{CO}$ mixing ratios by about $7 \mathrm{ppb}$ (Table 1, Fig. 10). This can be directly compared to the $9.6 \mathrm{ppbCO}$ found by Wang et al. (2010) for present-day conditions. However, they used a different atmospheric model and a previous version of GFED (version 2) with higher emission estimates. According to the ice core data from Wang et 

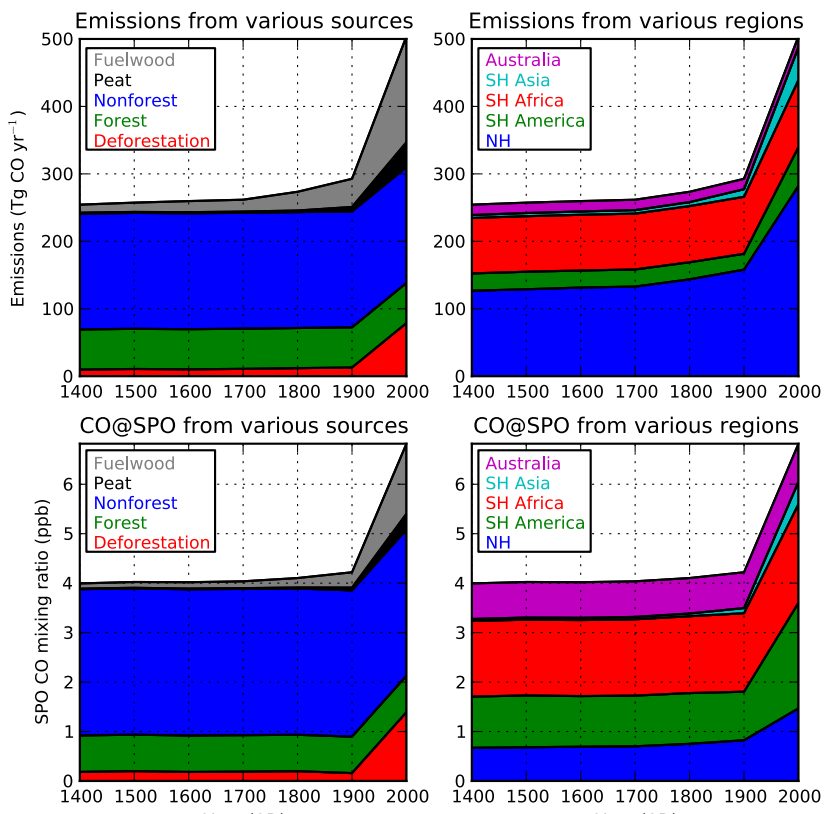
CO@SPO from various regions

Year (AD)

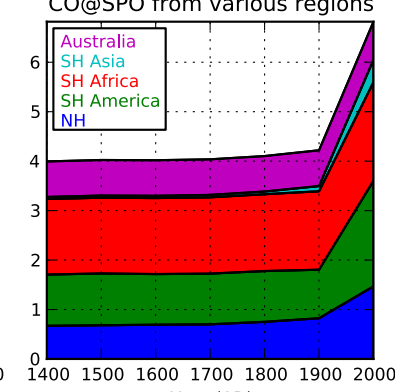

Year (AD)

Fig. 10. Reconstructed emissions and corresponding SPO CO mixing ratios when all sources except forest and "nonforest" (savanna, woodland, agricultural waste burning) were scaled with rural population density. NH is Northern Hemisphere, $\mathrm{SH}$ is Southern Hemisphere.

al. (2010) this has been $30 \mathrm{ppb}$ in the past for at least decadal-scale periods of time (Fig. 1).

The key questions we aimed to answer here is what could have caused this large difference, taking into account that several sources were likely lower in pre-industrial times than they are now, amounting to a decrease of about 3 ppb SPO $\mathrm{CO}$ mixing ratio (Fig. 10). The maximum difference to explain is thus about $26 \mathrm{ppb}$ ( $30 \mathrm{ppb}$ measured minus $4 \mathrm{ppb}$ simulated for those decades), and below we detail several scenarios that might have played a role.

\subsection{Potential causes of high pre-industrial SPO CO mixing ratios}

1. Clearing of forests in the temperate Northern Hemisphere: over the past centuries, large areas of forest in temperate regions have been cleared to make way for agriculture. This occurred mostly in the Northern Hemisphere and total cleared area was about 10 million $\mathrm{km}^{2}$ (Ramankutty and Foley, 1999). If we take typical literature values for biomass stocks, combustion completeness, emission factors, and the efficiency of $4.5 \mathrm{ppbCO}$ per Pg of $\mathrm{CO}$ combusted (the mean of forest and nonforest in Table 1), then total CO mixing ratio at SPO would be elevated by $26 \pm 14$ ppb (Table 3 ) if all burning from clearing of forests over the past three centuries happened in one year, or on average $0.09 \pm 0.05 \mathrm{ppb}$ per year over the past three centuries if clearing rates were

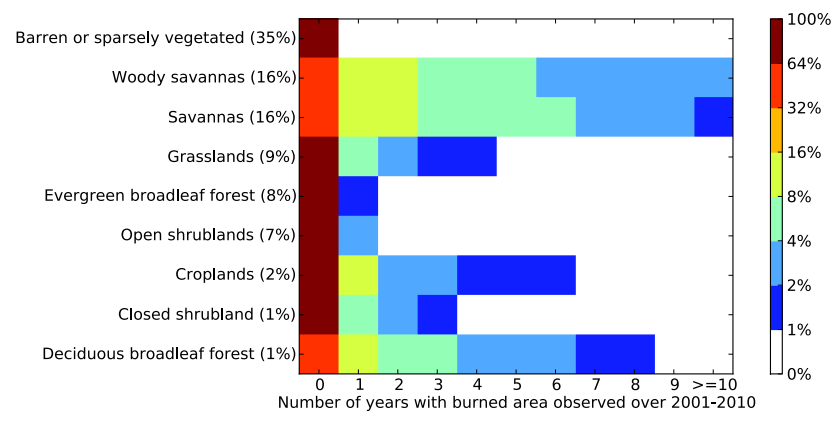

Fig. 11. Distribution of number of years with burned area observed over various land cover classes for Africa south of $30^{\circ} \mathrm{N}$. Only the land cover classes occupying more than $1 \%$ of the land area are shown. The graph can be read as follows: between 64 and $100 \%$ of the barren or sparsely vegetated land, which occupies $35 \%$ of the land area, had no area burned over the 2001-2010 period. Both land cover (MCD12Q1; Friedl et al., 2010) and burned area (MCD64A1; Giglio et al., 2009) were derived from MODIS 500-m data.

constant. Even though clearing rates were not constant and the history of deforestation is complex (Klein Goldewijk et al., 2010; Kaplan et al., 2009) temperate forest clearing can thus only explain a tiny fraction of the discrepancy.

2. Clearing of forests in the temperate Southern Hemisphere: the amount of temperate forest cleared in the Southern is much smaller than in the Northern Hemisphere, but due to its relative proximity Southern Hemisphere clearing fires could impact SPO CO mixing ratios much more. According to Ramankutty and Foley (1999) about 1 million $\mathrm{km}^{2}$ has been cleared in Argentina, Uruguay, Chile, and Australia. Using the same logic and biomass numbers as for the temperate forests, but an efficiency of 122 ppb CO per Pg of CO combusted (fuelwood combustion in Australia, the source category closest to SPO and overlapping with the areas where forests have been cleared) total $\mathrm{CO}$ elevation at SPO would be $69 \pm 39$ for one year of burning, or $0.23 \pm 0.13$ over $300 \mathrm{yr}$ under constant deforestation rates. This number is probably biased high because much of the clearing, especially in South America, was in lower biomass regions such as steppe. So even though these areas are relatively close to SPO, emissions rates were probably too low to explain a significant fraction of the SPO CO mixing ratio elevation. However, if much of this area was burned as frequently as suggested by Mouillot and Field (2005), then the contribution could be more significant; if 50 million ha was burned annually as grassland fires (Mouillot and Field, 2005), then the elevation could be $1.5 \pm 0.8 \mathrm{ppb} \mathrm{CO}$ at SPO for prolonged periods (Table 3 ).

3. Tropical forest conversion: although clearing rates in tropical forests are presently larger then those 
Table 3. CO mixing ratio enhancements at SPO due to various types of fires in selected regions using efficiencies from Table 1. NH is Northern Hemisphere, $\mathrm{SH}$ is Southern Hemisphere, $\mathrm{CC}$ is combustion completeness, and EF is emission factor.

\begin{tabular}{lrrrrrl}
\hline & $\begin{array}{r}\mathrm{Area}^{\mathrm{a}} \\
\left(\mathrm{m}^{2}\right)\end{array}$ & $\begin{array}{r}\text { Biomass } \\
\left(\mathrm{kg} \mathrm{DM} \mathrm{m}^{-2}\right)\end{array}$ & $\begin{array}{r}\mathrm{CC} \\
(-)\end{array}$ & $\begin{array}{r}\mathrm{EF}^{\mathrm{b}} \\
\left(\mathrm{g} \mathrm{CO} \mathrm{kg}^{-1} \mathrm{DM}^{-1}\right)\end{array}$ & $\begin{array}{r}\text { Efficiency } \\
(\mathrm{ppb} \text { CO@SPO } \\
\text { per Pg CO })\end{array}$ & $\begin{array}{l}\text { Mix. ratio } \\
(\mathrm{ppb} \text { CO @ } \\
\text { SPO })\end{array}$ \\
\hline NH Temperate deforestation & $1 \times 10^{13}$ & $21.4^{\mathrm{d}}$ & 0.25 & 106 & $4.5^{\mathrm{g}}$ & $25.5 \pm 14.3^{\mathrm{h}}$ \\
SH Temperate deforestation & $1 \times 10^{12}$ & $21.4^{\mathrm{d}}$ & 0.25 & 106 & 122.2 & $69.2 \pm 38.7^{\mathrm{h}}$ \\
SH Temperate grassland & $5 \times 10^{11}$ & $0.4^{\mathrm{e}}$ & 1.00 & 61 & 122.2 & $1.5 \pm 0.8$ \\
Amazon deforestation & $6 \times 10^{12}$ & $25.8^{\mathrm{f}}$ & 0.50 & 100 & 30.2 & $233.7 \pm 130.7^{\mathrm{h}}$ \\
Amazon grassland & $6 \times 10^{12}$ & $0.6^{\mathrm{e}}$ & 1.00 & 61 & 30.2 & $6.6 \pm 3.7$ \\
\hline
\end{tabular}

${ }^{a}$ Temperate deforestation extent based on cropland areas from Ramankutty and Foley (1999), SH temperate grassland burned area from Mouillot and Field (2005).

${ }^{b}$ Based on Andreae and Merlet (2001) with annual updates. ${ }^{c}$ Uncertainties based on assigned standard deviation of $25 \%$ for all variables, combined in quadrature.

${ }^{\mathrm{d}}$ Mean of cool temperate dry and cool temperate moist from Keith et al. (2009). ${ }^{\mathrm{e}}$ This work. ${ }^{\mathrm{f}}$ Mean of tropical wet and tropical dry from Keith et al. (2009). ${ }^{\mathrm{g}}$ Mean

of Northern Hemisphere forest and Northern Hemisphere fuelwood. ${ }^{\mathrm{h}}$ If all forest was cleared in one year.

in Northern temperate regions, this was the other way around up to about 1930 (Hansen et al., 2008; Houghton, 1999). However, since tropical forests are closer to SPO their impact on SPO CO mixing rations could be larger than temperate Northern Hemisphere forest clearing. Our simple rural population scaling indicated that emissions from tropical forest clearing during 1400 AD-1900 AD were on average about $25 \%$ of current emissions. It is impossible that current tropical forest clearing rates of about $0.5 \% \mathrm{yr}^{-1}$ (Hansen et al., 2008) have persisted for centuries; there simply was not that much tropical forest to clear. However, cleared areas can regrow so there is the potential for higher rates of forest clearing in the past, as long as those forests have had enough time to regrow. The same holds for slash and burn agriculture. This source of emissions, where smallholders clear patches of forest and use it for several years after which the land is abandoned, causes emissions without necessarily leading to permanent deforestation. In our scaling approach, this source of emissions is included in deforestation emissions and thus scaled with rural population density. It should be noted that there is large uncertainty in the population density estimates for these regions, especially for preColumbian times, and estimates vary by an order of magnitude (Bush et al., 2007). In the part below we will focus on the Amazon because it is the largest area of tropical forest and because the basin is relatively well studied. More importantly, there is evidence of use of fire in earlier time periods here.

Several studies using charcoal records from soils or lakes in the Amazon find a long history of humaninduced disturbance in the region (Bush et al., 2007; Cordeiro et al., 2008; Sanford et al., 1985; Turcq et al., 1998). There is also archaeological evidence for intensive occupation of parts of the Amazon (Heckenberger et al., 2008) and a scientific debate as to whether or not these areas are representative for larger parts of the Amazon (Bush et al., 2007; Heckenberger et al., 2003). In other words, it is uncertain whether the Amazon was to some extent parkland or a tropical forest in almost natural state. Similar to the clearing of temperate forests, we can calculate what the parkland hypothesis would mean for $\mathrm{CO}$ mixing ratios at SPO if we make several assumptions. The Amazon rainforest area was around 6 million $\mathrm{km}^{2}$. If the whole Amazon were to be deforested in one year using fires, the total $\mathrm{CO}$ mixing ratio at SPO would be elevated by $234 \pm 131 \mathrm{ppb}$ for this year (Table 3 ), or $2.3 \pm 1.3 \mathrm{ppb}$ if it happened over a century. This time window would imply deforestation rates of $1 \%$ per year compared to $0.5 \%$ per year over 2000-2005 aided by heavy machinery. Annual burning of grasslands that may have replaced the forests at that time could have enhanced SPO CO mixing ratios by $6.6 \pm 3.7 \mathrm{ppb}$ each year (Table 3 ).

Clearly, these are extreme scenarios and there is no evidence in the literature for complete clear-cut of the Amazon. However, these values can give some guidance to the impact of partial deforestation on SPO CO mixing ratio elevations, which is more likely in a parkland scenario. As an example, a more plausible $25 \%$ clear-cut over $100 \mathrm{yr}$ with $50 \%$ of the clear-cut area being burned annually could have elevated SPO CO mixing ratio with $1.4 \pm 0.8 \mathrm{ppb}$ at most $(25 \%$ of $2.3+12.5 \%$ of 6.6$)$. The most likely time period when this could have happened is the 15th century when both the charcoal and $\mathrm{CO}$ data reach high values. It is, however, also a time when ENSO activity was low (Cobb et al., 2003), so climate conditions were likely not favourable for large-scale use of fire in this humid region (van der Werf et al., 2008). In addition, the Law Dome $\mathrm{CO}_{2}$ record (Trudinger et al., 1999) shows no evidence for increased deforestation in the 15 th century, although a deforestation signal of about $0.5 \mathrm{PgC} \mathrm{yr}^{-1}$ for a century in our example of $25 \%$ deforestation would be relatively low compared to background fluxes. We conclude that while this 
source of emissions is a potential candidate in enhancing SPO CO mixing rations especially over timescales of a century, its magnitude may be barely enough to offset our calculated decrease in emissions due to lower rates of human induced fires. It cannot explain the much higher than modern mixing ratios seen in the $\mathrm{CO}$ ice core record.

4. Higher fire frequencies and/or larger areas available for burning in savannas and grasslands: although savannas have often been reported to burn annually or bi-annually, according to satellite-derived burned area data this is only true for a small fraction of the landscape, mostly African national parks where moisture levels are sufficient enough to produce a continuous fuel bed each year (Archibald et al., 2010). Other parts of the landscape that are more under human control burn less frequently than savannas that are in natural state due to road networks and other forms of landscape fragmentation, agricultural activity, and grazing (Archibald et al., 2009). This is shown in Fig. 11 where even in Africa, which is considered "the burning continent", about half of the area classified as savanna or woody savanna had no satellite burned area observations (Giglio et al., 2009) over 2001-2010. In monsoonal Australia with lower population densities, fires have been part of the landscape for a long time but no reliable record of fire activity can be constructed from historical accounts, except that fires were observed on most, if not all, landscapes (Preece, 2002). Charcoal data indicates that in most of Australia, fire activity has increased since 1400 AD with a peak around 1900 (Mooney et al., 2011). The African example where humans may have decreased fire activity is thus not necessarily representative for Australia and South America with lower population densities, but it does provide us with the remaining option for much higher emissions in pre-industrial times.

By running our model for multiple fire return times (Fig. 12) we have estimated the increase in emissions due to lower fire return times and/or larger areas available for burning. In the most extreme case where all non-forest area in the Southern Hemisphere would burn annually SPO CO mixing rations would be elevated by $25 \mathrm{ppb}$ (Table 2). This scenario is an upper bound and not very likely for at least two reasons. First, although most savannas can burn annually because they are productive enough to build up a continuous fuel bed each year, more arid regions do not support annual fires. As a case in point, the interior of Australia rarely burns but in 2011 it burned large areas for the first time in a decade due to excess rainfall in the wet season. Second, we assumed that the whole grid cell is available for burning while in reality landscape features such as rocky outcrops, escarpments, and river valleys will not burn.
In conclusion, we were unable to reproduce a realistic fire landscape that resulted in an increase in emissions large enough to reproduce the findings of Wang et al. (2010) unless we consider unlikely fire return times over all savanna areas or equally unlikely forest clearing rates. Taking the uncertainties in our approach into account though, we cannot definitively rule out that changes in biomass burning rates caused a quadrupling of the enhancement in SPO CO from fires.

\subsection{Are current biomass burning rates below pre-industrial ones?}

Our results indicated that while it was possible to construct a fire landscape that produced emissions much higher than current rates thus matching $\mathrm{CO}$ mixing ratios in ice core data, this fire landscape is not very likely in our opinion. This provides an incentive to replicate the $\mathrm{CO}$ results and its interpretation, ideally using a different ice core. If the results are reproduced, it implies a totally different fire landscape from the present, with large implications for climate and biogeochemical reconstructions. If not, it may spark the debate on the magnitude of current fire emissions rates compared to pre-industrial levels.

Prentice (2010) argued that current rates are at a historic low, which is a valid conclusion when interpreting the results of Wang et al. (2010) and Marlon et al. (2008). However, it neglects the findings of Ferretti et al. (2005) and Mischler et al. (2009) on $\mathrm{CH}_{4}$ in ice cores (see Fig. 1), which show that the highest fire activity occurs now with consequently an increase in fire activity over the past decades that is also supported by new CO data for the Northern Hemisphere (Wang et al., 2012). With regard to the charcoal record, one could argue that the observational coverage does not fully overlap with the current distribution of wildfires; by far the most observations are in the US and Europe which contribute less than $1 \%$ of total contemporary global carbon emissions (van der Werf et al., 2010). Ongoing work using the charcoal database shows that several crucial regions, including South America and Australia, display an increase over the past centuries (Marlon et al., 2013; Power et al., 2013; Mooney et al., 2011).

Weighting charcoal records with regional burned area or emissions estimates may be a useful approach to improve the representativeness of the charcoal record for global analyses. In addition, more records in Africa are necessary to understand how fire activity has changed in the past in this continent, which is crucial from a global fire perspective as currently this region accounts for $70 \%$ of global burned area (Giglio et al., 2010) and about $50 \%$ of global carbon and black carbon emissions (van der Werf et al., 2010). In addition, the çerrado (savanna) regions of South America may be key to comprehend the CO record as they impact SPO twice as strongly as Africa. 

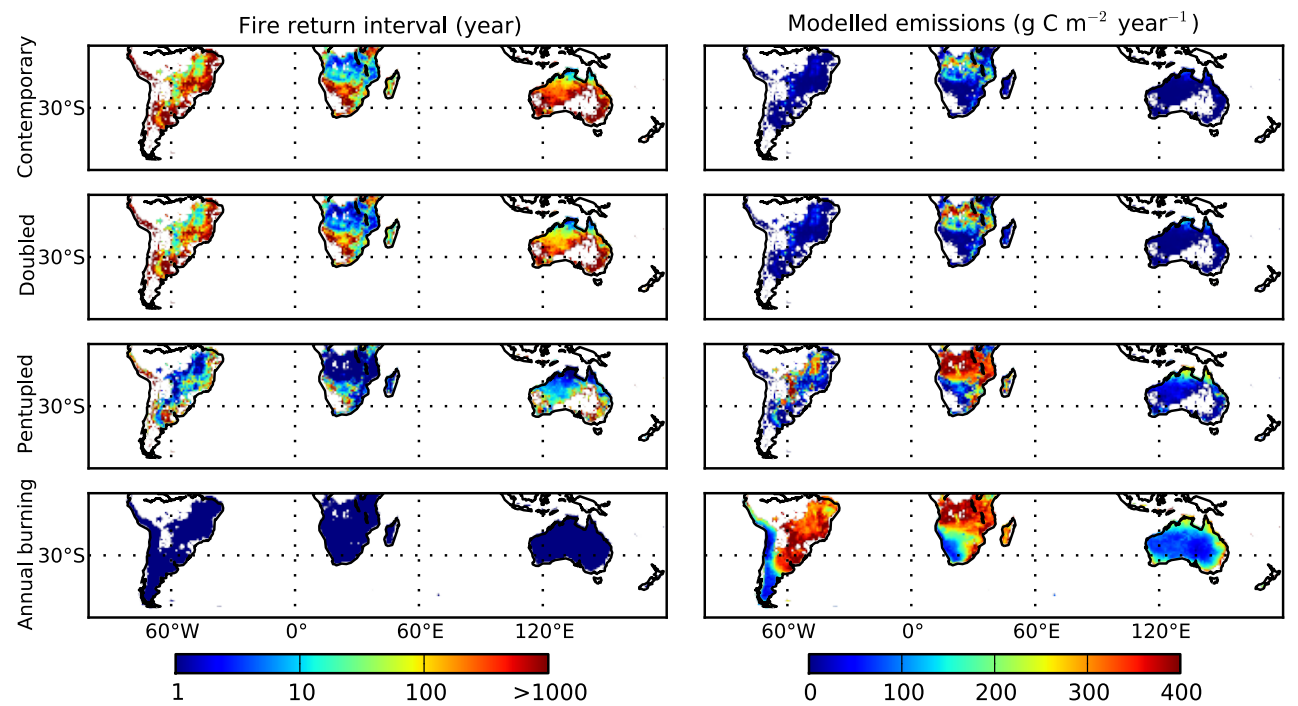

Fig. 12. Fire return intervals and corresponding emissions for contemporary, doubled, and pentupled fire return intervals, as well as for annual burning in all of the Southern Hemisphere's non-forest area.

Table 4. Modelled non-forest emissions and resulting CO mixing ratios at SPO for various uniformly applied fire return times (FRT) applied to all Southern Hemisphere (SH) areas not occupied by forest using three different approaches: (1) the standard run, (2) replacing NPP from the standard run with NPP derived from CASA based on satellite data, and (3) assuming fuels are independent of time since fire. The latter scenario assumes all biomass decomposes in the wet season so there is no carry-over of fuel to the following years.

\begin{tabular}{lrrrrrrr}
\hline & \multicolumn{2}{c}{ SH Emissions $\left(\mathrm{Tg} \mathrm{CO} \mathrm{yr}^{-1}\right)$} & & \multicolumn{2}{c}{ SPO mean CO mixing ratio (ppb) } \\
\cline { 2 - 3 } FRT (yr) & Standard & CASA NPP & No carry-over & & Standard & CASA NPP & No carry-over \\
\hline 1 & 880 & 825 & 880 & & 28.03 & 25.45 & 28.03 \\
2 & 724 & 685 & 440 & & 22.96 & 21.02 & 14.02 \\
4 & 521 & 499 & 220 & & 16.49 & 15.25 & 7.01 \\
8 & 322 & 311 & 110 & & 10.17 & 9.47 & 3.50 \\
16 & 174 & 169 & 55 & & 5.53 & 5.16 & 1.75 \\
32 & 89 & 86 & 28 & & 2.82 & 2.62 & 0.88 \\
64 & 44 & 43 & 14 & & 1.41 & 1.31 & 0.44 \\
128 & 22 & 21 & 7 & & 0.70 & 0.66 & 0.22 \\
\hline
\end{tabular}

\subsection{Uncertainties}

We performed several steps and each of those has uncertainties. Unfortunately they cannot easily be quantified, so we revert for a large part to a more qualitative discussion below. A Monte Carlo simulation of the GFED fire emissions estimates indicated that these emissions are uncertain to at least $20 \%(1 \sigma)$ and more likely to be conservative than too high. GFED is based on $500 \mathrm{~m}$ maps of burned area, and misses small fires such as agricultural fires. These are more prevalent in the Northern Hemisphere but there is a realistic chance that our estimates of fire emissions will increase when we can better address the importance of small fires (Randerson et al., 2012). This would lower the discrepancy that needs to be explained to match historic $\mathrm{CO}$ mixing ratios, but probably not by more than 1 or $2 \mathrm{ppb}$.
The atmospheric transport model was run for $6 \mathrm{yr}$ (20022007 ) to test the sensitivity to variations in meteorology and thus transport to SPO. Interannual variability in the sensitivity as reported in Table 1 was less than $3 \%$. Changes in largescale circulation patterns may have been more important but cannot be easily quantified (Lambert et al., 1990). Another source of uncertainty stems from changes in atmospheric composition; $\mathrm{CO}$ is mainly removed from reaction with the hydroxyl radical $(\mathrm{OH})$. If the $\mathrm{OH}$ concentration was reduced in pre-industrial times, lower emissions might suffice to explain the increase of CO at SPO. However, simulations of the global average pre-industrial OH-budget point to a relatively constant $\mathrm{OH}$ instead (Lelieveld et al., 2002). This is because in the pre-industrial an expected increase of $\mathrm{OH}$ due to lower $\mathrm{CH}_{4}$ concentrations was partly balanced by less recycling of $\mathrm{OH}$ due to lower $\mathrm{NO}_{\mathrm{x}}$ levels. On a regional scale, however, 
$\mathrm{OH}$ levels may have been different by up to $25 \%$ because the $\mathrm{CH}_{4}$ levels changed globally but the $\mathrm{NO}_{\mathrm{x}}$ levels changed mostly over the land surface. These non-linear interactions can be further explored using full chemistry-transport models (e.g., Stevenson et al., 2006), but are at least an order of magnitude smaller than the mismatch between current and past SPO CO concentrations as found in Wang et al. (2010).

The model we developed here to assess the sensitivity of savanna emissions to changes in fire return times, while simple, was able to mimic GFED emissions within about $80 \%$ of its variability. To test how sensitive our results were to the new NPP fields we replaced those with the CASA NPP values (Table 4). Lower NPP values translated to a reduction of up to $7 \%$ in emissions, indicating that it would be even more difficult for landscape fires to explain the discrepancy. We also tested the sensitivity of our approach to the amount of fuel that is carried over from one year to the other. In our approach and in GFED, not all biomass decomposes during the wet season so the amount of fuel increases over time (Fig. 6). This may be more representative for woody savannas while in grasslands and open savannas most of the fuel decomposes (Cheney and Sullivan, 2008). In other words, fuel may be more constant from year to year than our model with substantial fuel carry-over predicted. This did not influence our emission estimates for annual burning because in this case fuel build-up is irrelevant, but it did substantially lower emissions for those areas that burn infrequently to estimates well below those from GFED (Table 4). This analysis also showed that our results may overestimate the potential for savanna fires to account for the difference in SPO CO mixing ratios because emissions decreased compared to the standard run when fires do not burn annually.

\section{Conclusions}

We have used biogeochemical and atmospheric chemical transport modelling to investigate how fire emissions contributed to $\mathrm{CO}$ mixing ratios at a remote location at the South Pole and tried to answer what could have caused preindustrial biomass rates to exceed current rates by up to a factor of 4 as suggested by recent results using ice cores. Our main findings can be summarized as follows:

- The difference between the current contribution of fires to SPO CO mixing ratios $( \pm 7 \mathrm{ppb})$ and the values of around $30 \mathrm{ppb}$ during extended periods of the 15 th and 19 th century as found in ice cores is very large, especially when one considers that several human-driven fire emission sources including fuelwood burning and tropical peat fires were probably lower then than they are now. The only possible candidate for explaining all of the difference is savanna fires if they burned substantially larger areas and more frequently than they do now. It is likely that savanna fires were more extensive in earlier time periods because fuel beds were less fragmented. Thus, the amount of land available for burning was larger. In addition, fuel beds were probably denser due to lower grazing rates. However, to fully explain the difference in CO mixing ratios all of the Southern Hemisphere non-forest land had to burn annually or bi-annually during the highest fire episodes. This is not likely if only for the reason that in arid regions, not all savannas build up enough fuel each year to be able to burn annually.

- Increased emissions in Southern Hemisphere temperate forest, increased rates of charcoal production, and increased rates of deforestation and slash and burn agriculture in the tropical forests could have helped in explaining the excess biomass burning rates necessary to mimic pre-industrial CO SPO mixing ratios, but the magnitude of these sources is much smaller than that derived from savanna fires, even when extreme scenarios of deforestation are envisioned.

- There was substantial variability in the relative contribution of fires from different sources and different regions to SPO mixing ratios, even in the Southern Hemisphere. Per unit CO emissions, savanna fires in South America contributed twice as much to SPO CO mixing ratios as African savanna fires due to proximity to SPO in combination with different atmospheric transport pathways. The differences were largest between Australia and the Northern Hemisphere; fires burning in the former were over 8 times more efficient in influencing SPO CO mixing ratios than those burning in the latter. Care should thus be taken when interpreting $\mathrm{CO}$ mixing ratios at SPO as a proxy for Southern Hemisphere biomass burning rates due to the relatively short lifetime of $\mathrm{CO}$ of about two months on average and the variability in emission rates of $\mathrm{CO}$ per unit biomass combusted.

Our results call for a confirmation of the $\mathrm{CO}$ ice core measurements and their interpretation, as well as more charcoal records from savanna regions in South America and Africa. Both are needed to better understand how variable global fire rates have been over the past centuries and to answer the question whether current global fire emissions are unprecedentedly low (or high). With the current available information, this question cannot be fully answered but is crucial for climate reconstructions because of the importance of fires for several radiative forcing agents.

Acknowledgements. We thank Patricia Castellanos and Jennifer Marlon for helpful suggestions and Zhihui Wang, John Mak, and the Global Paleofire Working Group for making their data available. Guido van der Werf received support from the European Research Council (ERC), and Wouter Peters was partially supported by an NWO VIDI grant (864.08.012). Thijs van Leeuwen was supported by the Dutch User Support Programme from the 
Netherlands organization for scientific research (NWO) under program number GO/AO-11, and support for Louis Giglio was provided by National Aeronautics and Space Administration (NASA) grant NNX11AF96G.

Edited by: E. Wolff

\section{References}

Akagi, S. K., Yokelson, R. J., Wiedinmyer, C., Alvarado, M. J., Reid, J. S., Karl, T., Crounse, J. D., and Wennberg, P. O.: Emission factors for open and domestic biomass burning for use in atmospheric models, Atmos. Chem. Phys., 11, 4039-4072, doi:10.5194/acp-11-4039-2011, 2011.

Andreae, M. and Merlet, P.: Emission of trace gases and aerosols from biomass burning, Global Biogeochem. Cy., 15, 955-966, 2001.

Aragao, L. E. O. C. and Shimabukuro, Y. E.: The Incidence of Fire in Amazonian Forests with Implications for REDD, Science, 328, 1275-1278, doi:10.1126/science.1186925, 2010.

Archibald, S., Roy, D. P., van Wilgen, B. W., and Scholes, R. J.: What limits fire? An examination of drivers of burnt area in Southern Africa, Global Change Biol., 15, 613-630, doi:10.1111/j.1365-2486.2008.01754.x, 2009.

Archibald, S., Nickless, A., Govender, N., Scholes, R. J., and Lehsten, V.: Climate and the interannual variability of fire in southern Africa: a meta-analysis using long-term field data and satellite-derived burnt area data, Global Ecol. Biogeogr., 19, 794-809, doi:10.1111/j.1466-8238.2010.00568.x, 2010.

Arino, O., Casadio, S., and Serpe, D.: Global night-time fire season timing and fire count trends using the ATSR instrument series, Remote Sens. Environ., 116, 226-238, doi:10.1016/j.rse.2011.05.025, 2012.

Assonov, S. S., Brenninkmeijer, C. A. M., Jöckel, P., Mulvaney, R., Bernard, S., and Chappellaz, J.: Evidence for a CO increase in the SH during the 20th century based on firn air samples from Berkner Island, Antarctica, Atmos. Chem. Phys., 7, 295-308, doi:10.5194/acp-7-295-2007, 2007.

Balch, J. K., Nepstad, D. C., Brando, P. M., Curran, L. M., Portela, O., De Carvalho, O., and Lefebvre, P.: Negative fire feedback in a transitional forest of southeastern Amazonia, Glob. Change Biol., 14, 2276-2287, doi:10.1111/j.1365-2486.2008.01655.x, 2008.

Bowman, D. M. J. S., Balch, J. K., Artaxo, P., Bond, W. J., Carlson, J. M., Cochrane, M. A., D'Antonio, C. M., DeFries, R. S., Doyle, J. C., Harrison, S. P., Johnston, F. H., Keeley, J. E., Krawchuk, M. A., Kull, C. A., Marston, J. B., Moritz, M. A., Prentice, I. C., Roos, C. I., Scott, A. C., Swetnam, T. W., van der Werf, G. R., and Pyne, S. J.: Fire in the Earth System, Science, 324, 481-484, doi:10.1126/science.1163886, 2009.

Bowman, D. M. J. S., Balch, J., Artaxo, P., Bond, W. J., Cochrane, M. A., D’Antonio, C. M., DeFries, R., Johnston, F. H., Keeley, J. E., Krawchuk, M. A., Kull, C. A., Mack, M., Moritz, M. A., Pyne, S., Roos, C. I., Scott, A. C., Sodhi, N. S., and Swetnam, T. W.: The human dimension of fire regimes on Earth, J. Biogeogr., 38, 2223-2236, doi:10.1111/j.1365-2699.2011.02595.x, 2011.

Bush, M. B., Silman, M. R., de Toledo, M. B., Listopad, C., Gosling, W. D., Williams, C., de Oliveira, P. E., and Krisel, C.: Holocene fire and occupation in Amazonia: records from two lake districts, Philos. T. Roy. Soc. B, 362, 209-218, doi:10.1098/rstb.2006.1980, 2007.

Cheney, P. and Sullivan, A.: Grassfires; fuel, weather, and fire behaviour, CSIRO publishing, Collingwood, Australia, 160 pp., 2008

Cobb, K. M., Charles, C. D., Cheng, H., and Edwards, R. L.: El Nino/Southern Oscillation and tropical Pacific climate during the last millennium, Nature, 424, 271-276, doi:10.1038/nature01779, 2003.

Cochrane, M. K. and Barber, C. P.: Climate change, human land use and future fires in the Amazon, Glob. Change Biol., 15, 601-612, doi:10.1111/j.1365-2486.2008.01786.x, 2009.

Cook, G. D.: Fuel dynamics, nutrients, and atmospheric chemistry, edited by: Andersen, A. N., Cook, G. D., and Williams, R. J., Springer-Verlag, New York, 2003.

Cordeiro, R. C., Turcq, B., Suguio, K., da Silva, A. O., Sifeddine, A., and Volkmer-Ribeiro, C.: Holocene fires in East Amazonia (Caraja's), new evidences, chronology and relation with paleoclimate, Global Planet. Change, 61, 49-62, doi:10.1016/j.gloplacha.2007.08.005, 2008.

Falk, D. A., Heyerdahl, E. K., Brown, P. M., Farris, C., Fule, P. Z., McKenzie, D., Swetnam, T. W., Taylor, A. H., and Van Horne, M. L.: Multi-scale controls of historical forest-fire regimes: new insights from fire-scar networks, Front. Ecol. Environ., 9, 446454, doi:10.1890/100052, 2011.

Fernandes, P. and Botelho, H.: A review of prescribed burning effectiveness in fire hazard reduction, Int. J. Wildland Fire, 12, 117128, doi:10.1071/WF02042, 2003.

Ferretti, D., Miller, J., White, J., Etheridge, D., Lassey, K., Lowe, D., Meure, C., Dreier, M., Trudinger, C., van Ommen, T., and Langenfelds, R.: Unexpected changes to the global methane budget over the past 2000 years, Science, 309, 1714-1717, doi:10.1126/science.1115193, 2005.

Field, R. D., van der Werf, G. R., and Shen, S. S. P.: Human amplification of drought-induced biomass burning in Indonesia since 1960, Nat. Geosci., 2, 185-188, doi:10.1038/ngeo443, 2009.

Friedl, M. A., Sulla-Menashe, D., Tan, B., Schneider, A., Ramankutty, N., Sibley, A., and Huang, X.: MODIS Collection 5 global land cover: Algorithm refinements and characterization of new datasets, Remote Sens. Environ., 114, 168-182, doi:10.1016/j.rse.2009.08.016, 2010.

Giglio, L., Kendall, J., and Mack, R.: A multi-year active fire dataset for the tropics derived from the TRMM VIRS, Int. J. Remote Sens., 24, 4505-4525, doi:10.1080/0143116031000070283, 2003.

Giglio, L., Loboda, T., Roy, D. P., Quayle, B., and Justice, C. O.: An active-fire based burned area mapping algorithm for the MODIS sensor, Remote Sens. Environ., 113, 408-420, doi:10.1016/j.rse.2008.10.006, 2009.

Giglio, L., Randerson, J. T., van der Werf, G. R., Kasibhatla, P. S., Collatz, G. J., Morton, D. C., and DeFries, R. S.: Assessing variability and long-term trends in burned area by merging multiple satellite fire products, Biogeosciences, 7, 1171-1186, doi:10.5194/bg-7-1171-2010, 2010.

Hansen, J., Ruedy, R., Glascoe, J., and Sato, M.: GISS analysis of surface temperature change, J. Geophys. Res.-Atmos., 104, 30997-31022, 1999.

Hansen, M. C., Stehman, S. V., Potapov, P. V., Loveland, T. R., Townshend, J. R. G., DeFries, R. S., Pittman, K. W., 
Arunarwati, B., Stolle, F., Steininger, M. K., Carroll, M., and DiMiceli, C.: Humid tropical forest clearing from 2000 to 2005 quantified by using multitemporal and multiresolution remotely sensed data, P. Natl. Acad. Sci. USA, 105, 9439-9444, doi:10.1073/pnas.0804042105, 2008.

Heckenberger, M. J., Kuikuro, A., Kuikuro, U., Russell, J., Schmidt, M., Fausto, C., and Franchetto, B.: Amazonia 1492: Pristine forest or cultural parkland?, Science, 301, 1710-1714, 2003.

Heckenberger, M. J., Russell, J. C., Fausto, C., Toney, J. R., Schmidt, M. J., Pereira, E., Franchetto, B., and Kuikuro, A.: Pre-columbian urbanism, anthropogenic landscapes, and the future of the Amazon, Science, 321, 1214-1217, doi:10.1126/science.1159769, 2008.

Hooghiemstra, P. B., Krol, M. C., Meirink, J. F., Bergamaschi, P., van der Werf, G. R., Novelli, P. C., Aben, I., and Röckmann, T.: Optimizing global CO emission estimates using a fourdimensional variational data assimilation system and surface network observations, Atmos. Chem. Phys., 11, 4705-4723, doi:10.5194/acp-11-4705-2011, 2011.

Houghton, R.: The annual net flux of carbon to the atmosphere from changes in land use 1850-1990, Tellus B, 51, 298-313, 1999.

Houweling, S., van der Werf, G. R., Goldewijk, K. K., Roeckmann, T., and Aben, I.: Early anthropogenic $\mathrm{CH}_{4}$ emissions and the variation of $\mathrm{CH}_{4}$ and $13 \mathrm{CH}_{4}$ over the last millennium, Global Biogeochem. Cy., 22, GB1002, doi:10.1029/2007GB002961, 2008.

Huffman, G. J., Adler, R. F., Bolvin, D. T., and Gu, G.: Improving the Global Precipitation Record: GPCP Version 2.1, Geophys. Res. Lett., 36, L17808, doi:10.1029/2009GL040000, 2009.

Huijnen, V., Williams, J., van Weele, M., van Noije, T., Krol, M., Dentener, F., Segers, A., Houweling, S., Peters, W., de Laat, J., Boersma, F., Bergamaschi, P., van Velthoven, P., Le Sager, P., Eskes, H., Alkemade, F., Scheele, R., Nédélec, P., and Pätz, H.-W.: The global chemistry transport model TM5: description and evaluation of the tropospheric chemistry version 3.0, Geosci. Model Dev., 3, 445-473, doi:10.5194/gmd-3-445-2010, 2010.

Kaminski, T., Giering, R., and Heimann, M.: Sensitivity of the seasonal cycle of $\mathrm{CO}_{2}$ at remote monitoring stations with respect to seasonal surface exchange fluxes determined with the adjoint of an atmospheric transport model, Phys. Chem. Earth, 21, 457462, 1996.

Kaplan, J. O., Krumhardt, K. M., and Zimmerman, N.: The prehistoric and preindustrial deforestation of Europe, Quaternary Sci. Rev., 28, 3016-3034, doi:10.1016/j.quascirev.2009.09.028, 2009.

Kehrwald, N., Zangrando, R., Gabrielli, P., Jaffrezo, J.-L., Boutron, C., Barbante, C., and Gambaro, A.: Levoglucosan as a specific marker of fire events in Greenland snow, Tellus B, 64, 18196, doi:10.3402/tellusb.v64i0.18196, 2012.

Keith, H., Mackey, B. G., and Lindenmayer, D. B.: Re-evaluation of forest biomass carbon stocks and lessons from the world's most carbon-dense forests, P. Natl. Acad. Sci. USA, 106, 1163511640, doi:10.1073/pnas.0901970106, 2009.

Klein Goldewijk, K. , Beusen, A., and Janssen, P.: Long term dynamic modeling of global population and built-up area in a spatially explicit way, HYDE 3.1, Holocene, 20, 565-573, doi:10.1177/0959683609356587, 2010.

Kloster, S., Mahowald, N. M., Randerson, J. T., Thornton, P. E., Hoffman, F. M., Levis, S., Lawrence, P. J., Feddema, J. J., Ole- son, K. W., and Lawrence, D. M.: Fire dynamics during the 20th century simulated by the Community Land Model, Biogeosciences, 7, 1877-1902, doi:10.5194/bg-7-1877-2010, 2010.

Krinner, G. and Genthon, C.: Tropospheric transport of continental tracers towards Antarctica under varying climatic conditions, Tellus B, 55, 54-70, 2003.

Krol, M., Houweling, S., Bregman, B., van den Broek, M., Segers, A., van Velthoven, P., Peters, W., Dentener, F., and Bergamaschi, P.: The two-way nested global chemistry-transport zoom model TM5: algorithm and applications, Atmos. Chem. Phys., 5, 417432, doi:10.5194/acp-5-417-2005, 2005.

Kurz, W. and Apps, M.: A 70-year retrospective analysis of carbon fluxes in the Canadian forest sector, Ecol. Appl., 9, 526-547, 1999.

Lamarque, J.-F., Bond, T. C., Eyring, V., Granier, C., Heil, A., Klimont, Z., Lee, D., Liousse, C., Mieville, A., Owen, B., Schultz, M. G., Shindell, D., Smith, S. J., Stehfest, E., Van Aardenne, J., Cooper, O. R., Kainuma, M., Mahowald, N., McConnell, J. R., Naik, V., Riahi, K., and van Vuuren, D. P.: Historical (1850-2000) gridded anthropogenic and biomass burning emissions of reactive gases and aerosols: methodology and application, Atmos. Chem. Phys., 10, 7017-7039, doi:10.5194/acp10-7017-2010, 2010.

Lambert, G., Ardouin, B., and Sanak, J.: Atmospheric transport of trace elements toward Antarctica, Tellus B, 42, 76-82, 1990.

Lelieveld, J., Peters, W., Dentener, F., and Krol, M.: Stability of tropospheric hydroxyl chemistry, J. Geophys. Res.-Atmos., 107, 4715,, doi:10.1029/2002JD002272, 2002.

Marlon, J. R., Bartlein, P. J., Carcaillet, C., Gavin, D. G., Harrison, S. P., Higuera, P. E., Joos, F., Power, M. J., and Prentice, I. C.: Climate and human influences on global biomass burning over the past two millennia, Nat. Geosci., 1, 697-702, doi:10.1038/ngeo313, 2008.

Marlon, J. R., Bartlein, P. J., Daniau, A. L., Harrison, S. P., Tinner, W., and Tracy, S.: Global biomass burning: a synthesis and review of holocene paleofire records and their controls, Quaternary Sci. Rev., submitted, 2013.

McConnell, J. R., Edwards, R., Kok, G. L., Flanner, M. G., Zender, C. S., Saltzman, E. S., Banta, J. R., Pasteris, D. R., Carter, M. M., and Kahl, J. D. W.: 20th-century industrial black carbon emissions altered arctic climate forcing, Science, 317, 1381-1384, doi:10.1126/science.1144856, 2007.

Mieville, A., Granier, C., Liousse, C., Guillaume, B., Mouillot, F., Lamarque, J. F., Gregoire, J. M., and Petron, G.: Emissions of gases and particles from biomass burning during the 20th century using satellite data and an historical reconstruction, Atmos. Environ., 44, 1469-1477, doi:10.1016/j.atmosenv.2010.01.011, 2010.

Mischler, J. A., Sowers, T. A., Alley, R. B., Battle, M., McConnell, J. R., Mitchell, L., Popp, T., Sofen, E., and Spencer, M. K.: Carbon and hydrogen isotopic composition of methane over the last 1000 years, Global Biogeochem. Cy., 23, GB4024, doi:10.1029/2009GB003460, 2009.

Mollicone, D., Eva, H., and Achard, F.: Ecology Human role in Russian wild fires, Nature, 440, 436-437, doi:10.1038/440436a, 2006.

Monks, P. S., Granier, C., Fuzzi, S., Stohl, A., Williams, M. L., Akimoto, H., Amann, M., Baklanov, A., Baltensperger, U., Bey, I., Blake, N., Blake, R. S., Carslaw, K., Cooper, O. R., Dentener, F., Fowler, D., Fragkou, E., Frost, G. J., Generoso, S., Ginoux, 
P., Grewe, V., Guenther, A., Hansson, H. C., Henne, S., Hjorth, J., Hofzumahaus, A., Huntrieser, H., Isaksen, I. S. A., Jenkin, M. E., Kaiser, J., Kanakidou, M., Klimont, Z., Kulmala, M., Laj, P., Lawrence, M. G., Lee, J. D., Liousse, C., Maione, M., McFiggans, G., Metzger, A., Mieville, A., Moussiopoulos, N., Orlando, J. J., O'Dowd, C. D., Palmer, P. I., Parrish, D. D., Petzold, A., Platt, U., Poeschl, U., Prevot, A. S. H., Reeves, C. E., Reimann, S., Rudich, Y., Sellegri, K., Steinbrecher, R., Simpson, D., Brink, ten, H., Theloke, J., van der Werf, G. R., Vautard, R., Vestreng, V., Vlachokostas, C., and Glasow, von, R.: Atmospheric composition change - global and regional air quality, Atmos. Environ., 43, 5268-5350, doi:10.1016/j.atmosenv.2009.08.021, 2009.

Mooney, S. D., Harrison, S. P., Bartlein, P. J., Daniau, A.L., Stevenson, J., Brownlie, K. C., Buckman, S., Cupper, M., Luly, J., Black, M., Colhoun, E., D'Costa, D., Dodson, J., Haberle, S., Hope, G. S., Kershaw, P., Kenyon, C., McKenzie, M., and Williams, N.: Late Quaternary fire regimes of Australasia, Quaternary Sci. Rev., 30, 28-46, doi:10.1016/j.quascirev.2010.10.010, 2011

Mouillot, F. and Field, C.: Fire history and the global carbon budget: a 1 degrees $\times 1$ degrees fire history reconstruction for the 20th century, Global Change Biol., 11, 398-420, doi:10.1111/j.13652486.2005.00920.x, 2005.

Nepstad, D., Verissimo, A., Alencar, A., Nobre, C., Lima, E., Lefebvre, P., Schlesinger, P., Potter, C., Moutinho, P., Mendoza, E., Cochrane, M., and Brooks, V.: Large-scale impoverishment of Amazonian forests by logging and fire, Nature, 398, 505-508, 1999.

Olivier, J. G. J., Janssens-Maenhout, G., Peters, J. A. H. W., and Wilson, J.: Long-term trend in global $\mathrm{CO}_{2}$ emissions, 2011 report, PBL/JRC, The Hague, 2011.

Olson, J. S.: Energy Storage and the Balance of Producers and Decomposers in Ecological Systems, Ecology, 44, 322-331, doi:10.2307/1932179, 1963.

Pechony, O. and Shindell, D. T.: Driving forces of global wildfires over the past millennium and the forthcoming century, P. Natl. Acad. Sci. USA, 107, 19167-19170, doi:10.1073/pnas.1003669107, 2010.

Power, M. J., Marlon, J., Ortiz, N., Bartlein, P. J., Harrison, S. P., Mayle, F. E., Ballouche, A., Bradshaw, R. H. W., Carcaillet, C., Cordova, C., Mooney, S., Moreno, P. I., Prentice, I. C., Thonicke, K., Tinner, W., Whitlock, C., Zhang, Y., Zhao, Y., Ali, A. A., Anderson, R. S., Beer, R., Behling, H., Briles, C., Brown, K. J., Brunelle, A., Bush, M., Camill, P., Chu, G. Q., Clark, J., Colombaroli, D., Connor, S., Daniau, A. L., Daniels, M., Dodson, J., Doughty, E., Edwards, M. E., Finsinger, W., Foster, D., Frechette, J., Gaillard, M. J., Gavin, D. G., Gobet, E., Haberle, S., Hallett, D. J., Higuera, P., Hope, G., Horn, S., Inoue, J., Kaltenrieder, P., Kennedy, L., Kong, Z. C., Larsen, C., Long, C. J., Lynch, J., Lynch, E. A., McGlone, M., Meeks, S., Mensing, S., Meyer, G., Minckley, T., Mohr, J., Nelson, D. M., New, J., Newnham, R., Noti, R., Oswald, W., Pierce, J., Richard, P. J. H., Rowe, C., Goni, M. F. S., Shuman, B. N., Takahara, H., Toney, J., Turney, C., Urrego-Sanchez, D. H., Umbanhowar, C., Vandergoes, M., Vanniere, B., Vescovi, E., Walsh, M., Wang, X., Williams, N., Wilmshurst, J., and Zhang, J. H.: Changes in fire regimes since the Last Glacial Maximum: an assessment based on a global synthesis and analysis of charcoal data, Clim. Dynam., 30, 887-907, doi:10.1007/s00382-007-0334-x, 2008.
Power, M., Mayle, F., Bartlein, P., Marlon, J., Anderson, R., Behling, H., Brown, K., Carcaillet, C., Colombaroli, D., Gavin, D., Hallett, D., Horn, S., Kennedy, L., Lane, C., Longo, C., Moreno, P., Paitre, C., Robinson, G., Taylor, Z., and Walsh, M.: Climatic control of the biomass-burning decline in the Americas after AD 1500, Holocene, 23, 3-13, doi:10.1177/0959683612450196, 2013.

Preece, N.: Aboriginal fires in monsoonal Australia from historical accounts, J. Biogeogr., 29, 321-336, 2002.

Prentice, I. C.: The Burning Issue, Science, 330, 1636-1637, doi:10.1126/science.1199809, 2010.

Ramankutty, N. and Foley, J.: Estimating historical changes in global land cover: Croplands from 1700 to 1992, Global Biogeochem. Cy., 13, 997-1027, 1999.

Randerson, J. T., Chen, Y., van der Werf, G. R., Rogers, B. M., and Morton, D. C.: Global burned area and biomass burning emissions from small fires, J. Geophys. Res., 117, G04012, doi:10.1029/2012JG002128, 2012.

Roy, D., Jin, Y., Lewis, P., and Justice, C.: Prototyping a global algorithm for systematic fireaffected area mapping using MODIS time series data, Remote Sens. Environ., 97, 137-162, doi:10.1016/j.rse.2005.04.007, 2005.

Sanford, R., Saldarriaga, J., Clark, K., Uhl, C., and Herrera, C.: Amazon Rainforest Fires, Science, 227, 53-55, 1985.

Sapart, C. J., Monteil, G., Prokopiou, M., van de Wal, R. S. W., Kaplan, J. O., Sperlich, P., Krumhardt, K. M., van der Veen, C.Houweling, S., Krol, M. C., Blunier, T., Sowers, T., Martinerie, P., Witrant, E., Dahl-Jensen, D., and Rockmann, T.: Natural and anthropogenic variations in methane sources during the past two millennia, Nature, 490, 85-88, doi:10.1038/nature11461, 2012

Savadogo, P., Zida, D., Sawadogo, L., Tiveau, D., Tigabu, M., and Oden, P. C.: Fuel and fire characteristics in savanna-woodland of West Africa in relation to grazing and dominant grass type, Int. J. Wildland Fire, 16, 531-539, doi:10.1071/WF07011, 2007.

Scott, A. C. and Glasspool, I. J.: The diversification of Paleozoic fire systems and fluctuations in atmospheric oxygen concentration, P. Natl. Acad. Sci. USA, 103, 10861-10865, doi:10.1073/pnas.0604090103, 2006.

Seiler, W. and Crutzen, P.: Estimates of Gross and Net Fluxes of Carbon Between the Biosphere and the Atmosphere From Biomass Burning, Climatic Change, 2, 207-247, 1980.

Spivakovsky, C., Logan, J., Montzka, S., Balkanski, Y., ForemanFowler, M., Jones, D., Horowitz, L., Fusco, A., Brenninkmeijer, C., Prather, M., Wofsy, S., and McElroy, M.: Threedimensional climatological distribution of tropospheric $\mathrm{OH}$ : Update and evaluation, J. Geophys. Res.-Atmos., 105, 8931-8980, 2000.

Stevenson, D. S., Dentener, F. J., Schultz, M. G., Ellingsen, K., van Noije, T. P. C., Wild, O., Zeng, G., Amann, M., Atherton, C. S., Bell, N., Bergmann, D. J., Bey, I., Butler, T., Cofala, J., Collins, W. J., Derwent, R. G., Doherty, R. M., Drevet, J., Eskes, H. J., Fiore, A. M., Gauss, M., Hauglustaine, D. A., Horowitz, L. W., Isaksen, I. S. A., Krol, M. C., Lamarque, J.-F., Lawrence, M. G., Montanaro, V., Müller, J.-F., Pitari, G., Prather, M. J., Pyle, J. A., Rast, S., Rodriguez, J. M., Sanderson, M. G., Savage, N. H., Shindell, D. T., Strahan, S. E., Sudo, K., and Szopa, S.: Multi-model ensemble simulations of present-day and near-future tropospheric ozone, J. Geophys. Res., 111, D08301, doi:10.1029/2005JD006338, 2006 
Swetnam, T. W. and Anderson, R. S.: Fire Climatology in the western United States: introduction to special issue, Int. J. Wildland Fire, 17, 1-7, doi:10.1071/WF08016, 2008.

Thonicke, K., Prentice, I., and Hewitt, C.: Modeling glacialinterglacial changes in global fire regimes and trace gas emissions, Global Biogeochem. Cy., 19, GB3008, doi:10.1029/2004GB002278, 2005.

Trudinger, C., Enting, I., Francey, R., Etheridge, D., and Rayner, P.: Long-term variability in the global carbon cycle inferred from a high-precision $\mathrm{CO}_{2}$ and $\delta 13 \mathrm{C}$ ice-core record, Tellus $\mathrm{B}, 51,233-$ 248, 1999.

Turcq, B., Sifeddine, A., Martin, L., Absy, M., Soubies, F., Suguio, K., and Volkmer-Ribeiro, C.: Amazonia rainforest fires: A lacustrine record of 7000 years, Ambio, 27, 139-142, 1998.

van der Werf, G. R., Randerson, J. T., Giglio, L., Gobron, N., and Dolman, A. J.: Climate controls on the variability of fires in the tropics and subtropics, Global Biogeochem. Cy., 22, GB3028, doi:10.1029/2007GB003122, 2008.

van der Werf, G. R., Randerson, J. T., Giglio, L., Collatz, G. J., Mu, M., Kasibhatla, P. S., Morton, D. C., DeFries, R. S., Jin, Y., and van Leeuwen, T. T.: Global fire emissions and the contribution of deforestation, savanna, forest, agricultural, and peat fires (19972009), Atmos. Chem. Phys., 10, 11707-11735, doi:10.5194/acp10-11707-2010, 2010. van Leeuwen, T. T. and van der Werf, G. R.: Spatial and temporal variability in the ratio of trace gases emitted from biomass burning, Atmos. Chem. Phys., 11, 3611-3629, doi:10.5194/acp11-3611-2011, 2011.

Von Danckelman, A.: Die Bewolkungsverhaltnisse des sudwestlichen Afrikas, Meteorol. Z., 301-311, 1884.

Wang, Z., Chappellaz, J., Park, K., and Mak, J. E.: Large Variations in Southern Hemisphere Biomass Burning During the Last 650 Years, Science, 330, 1663-1666, doi:10.1126/science.1197257, 2010.

Wang, Z., Chappellaz, J., Martinerie, P., Park, K., Petrenko, V., Witrant, E., Emmons, L. K., Blunier, T., Brenninkmeijer, C. A. M., and Mak, J. E.: The isotopic record of Northern Hemisphere atmospheric carbon monoxide since 1950: implications for the CO budget, Atmos. Chem. Phys., 12, 4365-4377, doi:10.5194/acp-12-4365-2012, 2012.

Yevich, R. and Logan, J.: An assessment of biofuel use and burning of agricultural waste in the developing world, Global Biogeochem. Cy., 17, 1095, doi:10.1029/2002GB001952, 2003. 